\title{
Strabismus Disrupts Binocular Synaptic Integration in Primary Visual Cortex
}

\author{
Benjamin Scholl, Andrew Y. Y. Tan, and Nicholas J. Priebe \\ Center for Perceptual Systems, Section of Neurobiology, School of Biological Sciences, College of Natural Sciences, The University of Texas at Austin, \\ Austin, Texas 78705
}

Visual disruption early in development dramatically changes how primary visual cortex neurons integrate binocular inputs. The disruption is paradigmatic for investigating the synaptic basis of long-term changes in cortical function, because the primary visual cortex is the site of binocular convergence. The underlying alterations in circuitry by visual disruption remain poorly understood. Here we compare membrane potential responses, observed via whole-cell recordings in vivo, of primary visual cortex neurons in normal adult cats with those of cats in which strabismus was induced before the developmental critical period. In strabismic cats, we observed a dramatic shift in the ocular dominance distribution of simple cells, the first stage of visual cortical processing, toward responding to one eye instead of both, but not in complex cells, which receive inputs from simple cells. Both simple and complex cells no longer conveyed the binocular information needed for depth perception based on binocular cues. There was concomitant binocular suppression such that responses were weaker with binocular than with monocular stimulation. Our estimates of the excitatory and inhibitory input to single neurons indicate binocular suppression that was not evident in synaptic excitation, but arose de novo because of synaptic inhibition. Further constraints on circuit models of plasticity result from indications that the ratio of excitation to inhibition evoked by monocular stimulation decreased mainly for nonpreferred eye stimulation. Although we documented changes in synaptic input throughout primary visual cortex, a circuit model with plasticity at only thalamocortical synapses is sufficient to account for our observations.

\section{Introduction}

Binocular information about the visual world first converges in mammals in primary visual cortex (V1). The cortical circuitry which integrates binocular information develops normally only with requisite visual experience (Katz and Crowley, 2002; Hensch, 2004; Huberman et al., 2008). Strabismus, a misalignment in the visual axes of the two eyes, is a disorder in humans preventing appropriate fusion of the two retinal images (Levi et al., 1979; Von Noorden and Campos, 2002; Economides et al., 2012). Rearing animals with strabismus induced before the critical period leads to three major differences in V1 response properties. First, neurons are more monocular, responding more strongly to a stimulus presented to one eye than to the other (Hubel and Wiesel, 1965; Blakemore, 1976; Shatz et al., 1977; Löwel, 1994; Löwel et al., 1998; Engelmann et al., 2002). Second, neurons are less disparity selective, responding more uniformly regardless of the disparity between stimuli presented simultaneously to both eyes, leading to a loss of ability to estimate object

Received May 1, 2013; revised Sept. 15, 2013; accepted Sept. 18, 2013.

Author contributions: N.J.P. designed research; B.S., A.Y.-Y.T., and N.J.P. performed research; B.S., A.Y.-Y.T., and N.J.P. analyzed data; B.S., A.Y.-Y.T., and N.J.P. wrote the paper.

This work was supported by grants from the National Institutes of Health (EY-019288) and the Pew Charitable Trusts. We are grateful to Jessica Hanover and Wesley Thompson for illuminating discussions and comments, to Jonathan Horton for guidance on experimental methods, and to Dr. Lilliana McCallion for help on our initial surgeries.

Correspondence should be addressed to Nicholas J. Priebe, Center for Perceptual Systems, Section of Neurobiology, The University of Texas at Austin, 2401 Speedway, Austin, TX 78705. E-mail: nicholas@mail.utexas.edu.

DOI:10.1523/JNEUROSCI.1831-13.2013

Copyright $\odot 2013$ the authors $\quad 0270-6474 / 13 / 3317108-15 \$ 15.00 / 0$ depth visually (Chino et al., 1994; Smith et al., 1997). Third, neurons are binocularly suppressed, responding more weakly to binocular than to monocular stimulation (Sengpiel and Blakemore, 1994; Sengpiel et al., 1994).

While the effects of strabismus on V1 neuron response properties have been extensively studied using extracellular recordings, the underlying changes in cortical circuitry remain poorly understood (Hubel and Wiesel, 1965; Blakemore, 1976; Crewther et al., 1985; Chino et al., 1994; Roelfsema et al., 1994; Sengpiel and Blakemore, 1994; Sengpiel et al., 1994, 2006; Fries et al., 1997; Smith et al., 1997; Schmidt et al., 2004; Ranson et al., 2012). We accordingly performed whole-cell recordings in vivo to characterize the differences in synaptic input to V1 neurons of normal and strabismic cats. We observed that strabismus increased the monocularity of membrane potential in V1 simple cells, the first stage of visual cortical processing, but not in V1 complex cells, which receive inputs from simple cells. In strabismic animals, membrane potential and spiking responses of both simple and complex cells were less disparity selective, and no longer conveyed binocular information needed for depth perception from binocular cues. There was accompanying binocular suppression such that membrane potential and spiking responses were weaker during binocular than monocular stimulation. Estimates of excitatory and inhibitory input onto single neurons indicated binocular suppression that was not evident in synaptic excitation, but arose due to changes in the amount of excitatory and inhibitory synaptic drive: excitatory inputs were more monocular than inhibitory inputs. Although we documented changes in synaptic input in both simple and complex cells, a circuit model with 
plasticity at only thalamocortical synapses is sufficient to account for our observations (Khibnik et al., 2010).

\section{Materials and Methods}

All procedures were approved by the University of Texas at Austin Institutional Animal Care and Use Committee.

Strabismus surgery. Animals were anesthetized with isoflurane (1-3\%) and the medial rectus of the right eye was severed before the critical period (9-15 d old) to induce exotropic strabismus (divergent squint; Hubel and Wiesel, 1965; Yinon and Auerbach, 1975; Chino et al., 1983, 1994; Freeman and Tsumoto, 1983; Kalil et al., 1984; Löwel et al., 1998; Engelmann et al., 2002). Exotropia was chosen over esotropia (convergent squint) for comparison with previous key studies (Hubel and Wiesel, 1965; Chino et al., 1983, 1994). Body temperature, breathing rate, blood oxygenation $\left(\mathrm{SPO}_{2}\right)$, and autonomic signs were continuously monitored and maintained. Antibiotic ophthalmic ointment was placed on the eye, and the animal was monitored for at least $24 \mathrm{~h}$ after surgery. Deviation of the right eye was checked throughout the visual critical period. Physiology measurements were made 3-24 months after surgery. Strabismus was generated in 11 animals from four litters. In two animals, severance of the medial rectus was repeated because the muscle reattached several days after the first procedure. In three litters, two animals underwent a sham procedure where the ocular muscle was left intact. The 6 sham animals were used in addition to 14 normal adult animals. Throughout the text, strabismic animals are compared to normal animals, which includes both litter-matched shams and controls that underwent no sham surgery. We combined normal and litter-matched shams because we found no difference in ocular dominance or disparity selectivity between these two groups.

Physiology. Experiments were performed as described previously using anesthetized, paralyzed female and male cats $(2-5 \mathrm{~kg}$; Priebe and Ferster, 2006). Anesthesia was induced with ketamine $(5-15 \mathrm{mg} / \mathrm{kg})$ and acepromazine $(0.7 \mathrm{mg} / \mathrm{kg})$, followed by intravenous administration of a mixture of propofol and sufentanil (Yu and Ferster, 2010). Once a tracheotomy was performed, the animal was placed in a stereotaxic frame for the duration of the experiment. Recording stability was increased by suspending the thoracic vertebrae from the stereotactic frame and performing a pneumothoracotomy. Eye drift was minimized with intravenous infusion of vecuronium bromide. Anesthesia was maintained during the course of the experiment with continuous infusion of propofol and sufentanil ( $6-9 \mathrm{mg} / \mathrm{kg} / \mathrm{hr}$ and $1-1.5 \mu \mathrm{g} / \mathrm{kg} / \mathrm{hr}$, respectively). Body temperature $\left(38.3^{\circ} \mathrm{C}\right)$, electrocardiogram, $\mathrm{EEG}, \mathrm{CO}_{2}$, blood pressure, and autonomic signs were continuously monitored and maintained. The nictitating membranes were retracted using phenylephrine hydrochloride and the pupils were dilated using topical atropine. Contact lenses were inserted to protect the corneas. Supplementary lenses were selected by direct ophthalmoscopy to focus the display screen onto the retina.

Extracellular recordings. Extracellular electrodes (1-2 M $\Omega$; MicroProbes for Life Sciences) were advanced into primary visual cortex (cat, area 17, $\sim 2 \mathrm{~mm}$ lateral of midline) with a motorized drive (MP-285; Sutter Instrument). After the electrode was in place, warm agarose solution $(2-4 \%$ in normal saline) was placed over the craniotomy to protect the surface of the cortex and reduce pulsations. Action potentials were identified using a dual window discriminator (Bak Electronics, DDIS-1). The time of action potentials and raw extracellular traces were recorded for later analysis.

Whole-cell recordings. Blind whole-cell recordings were obtained in vivo (Pei et al., 1991; Ferster and Jagadeesh, 1992; Margrie et al., 2002). As a reference electrode, a silver/silver chloride wire was inserted into muscle near the base of the skull and covered with $4 \%$ agarose in normal saline to reduce changes in the surrounding fluid and concomitant changes in associated junction potentials. The potential of the CSF was assumed to be uniform and equal to that of the reference electrode. Pipettes $(8-12 \mathrm{M} \Omega$ ) were pulled from $1.2 \mathrm{~mm}$ outer diameter, $0.7 \mathrm{~mm}$ inner diameter KG-33 borosilicate glass capillaries (King Precision Glass) on a P-2000 micropipette puller (Sutter Instrument) to record from neurons $250-850 \mu \mathrm{m}$ below the cortical surface. To record membrane potential and spike responses, pipettes were filled with the following (in mM): $135 \mathrm{~K}$-gluconate, $4 \mathrm{NaCl}$, 0.5 EGTA, $2 \mathrm{MgATP}, 10$ phosphocreatine disodium, and 10 HEPES, pH adjusted to 7.3 with $\mathrm{KOH}$ (SigmaAldrich). Current-clamp recordings were performed with a MultiClamp 700B patch-clamp amplifier (Molecular Devices). Current flow out of the amplifier into the patch pipette was considered positive. Resting membrane potentials ranged from -50 to $-80 \mathrm{mV}$. Series resistances ranged from 30 to $100 \mathrm{M} \Omega$.

Stimuli. Visual stimuli were generated by a Macintosh computer (Apple) using the Psychophysics Toolbox (Brainard, 1997; Pelli, 1997) for Matlab (Mathworks) and presented dichoptically using two Sony video monitors (GDM-F520) placed $50 \mathrm{~cm}$ from the animal's eyes. The video monitors had a noninterlaced refresh rate of $100 \mathrm{~Hz}$ and a spatial resolution of $1024 \times 768$ pixels, which subtended $40 \times 30 \mathrm{~cm}\left(44 \times 34^{\circ}\right.$ in cat). The video monitors had a mean luminance of $40 \mathrm{~cd} / \mathrm{cm}^{2}$. Drifting grating stimuli were presented for $4 \mathrm{~s}$, preceded and followed by $250 \mathrm{~ms}$ blank (mean luminance) periods. Spontaneous activity was measured with blank periods interleaved with drifting grating stimuli and lasting the same duration. We characterized stimulus orientation, spatial frequency $\left(0.20-1.0\right.$ cycles/degree), spatial location, and size $\left(0.5-2^{\circ}\right.$ diameter) best evoking a response in the eye that elicited the strongest response. Upon isolating a neuron, stimulus parameters were coarsely mapped manually and then fine-tuned after systematic measurements of orientation and spatial selectivity. Binocular stimuli were presented dichoptically using the preferred stimulus parameters at 2-4 Hz temporal frequency and $90 \%$ contrast. A mirror was placed directly in front of the contralateral eye to reflect receptive field locations onto a separate monitor. The angle and location of the mirror was adjusted to avoid occlusion of the field of view for the ipsilateral eye. To measure binocular interactions we systematically changed the spatial phase of one grating while holding the spatial phase of the other grating constant (Ohzawa and Freeman, 1986a,b). Relative phase disparities used ranged from -180 to $135^{\circ}$. All binocular and monocular stimuli were presented during the same block and pseudorandomly interleaved.

Analysis. To compare estimates of subthreshold membrane potential and suprathreshold spikes, raw records were low-pass filtered with a cutoff at $100 \mathrm{~Hz}$ to remove spikes. Spikes were identified on the basis of the larger deflections in membrane potential. Spiking (from extracellular and intracellular records) and membrane potential responses for each stimulus were cycle averaged across trials following removal of the first cycle. The Fourier transform was used to calculate the mean $\left(\mathrm{F}_{0}\right)$ and modulation amplitude $\left(\mathrm{F}_{1}\right)$ of each cycle-averaged response. Simple and complex cells were separated by computing the modulation ratio $\left(\mathrm{F}_{1} / \mathrm{F}_{0}\right)$ for spiking responses to the preferred monocular stimulus; neurons with modulation ratios larger than 1 are considered simple. Peak responses were defined as the sum of the mean and modulation $\left(\mathrm{F}_{0}+\mathrm{F}_{1}\right)$. All peak responses are reported after subtraction of the mean spontaneous activity. Mean spontaneous activity for spiking activity and membrane potential fluctuations were measured during blank (mean luminance) periods. Error bars represent SEM unless otherwise indicated. Excitatory and inhibitory conductances were estimated as described previously (Anderson et al., 2000a).

In normal animals, we preformed a total of 69 extracellular recordings (simple, 32; complex, 37) and 76 intracellular recordings (simple, 52; complex, 24). In strabismic animals, we preformed a total of 113 extracellular recordings (simple, 42; complex, 71) and 79 intracellular recordings (simple, 48; complex, 31). A subset of intracellular records exhibited little or no spiking activity, and these records were used for analysis of only subthreshold membrane potential. Nonspiking neurons are those from which visual stimulation did not evoke spiking responses; however, these neurons did have the capacity to elicit action potentials, as verified with current injection. Intracellular records with sufficient spiking activity were identified as having a peak response of more than spikes per second to the preferred stimulus. In normal animals, 52 of 76 intracellular records had sufficient spiking responses (simple, 38; complex, 14), and in strabismic animals, 57 of 79 intracellular records had sufficient spiking responses (simple, 42; complex, 15).

To describe the nonlinear transformation between membrane potential and spike rate, we modeled the threshold nonlinearity by fitting the relationship between trial-averaged membrane potential and spike rate 
Normal

A

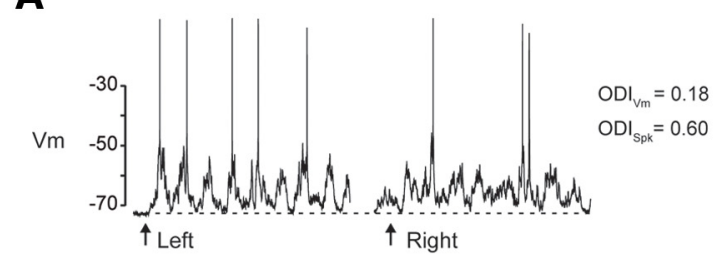

B

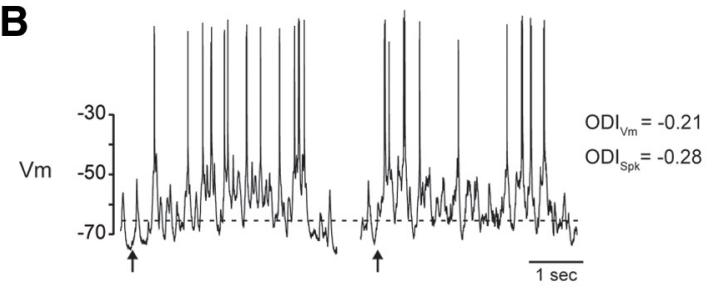

E

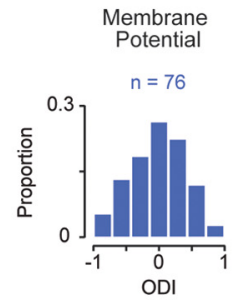

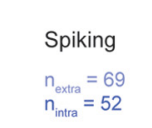

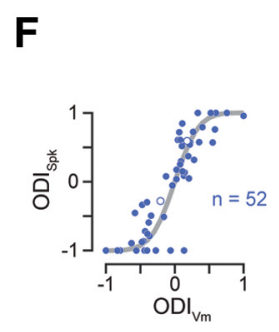

C

Strabismic

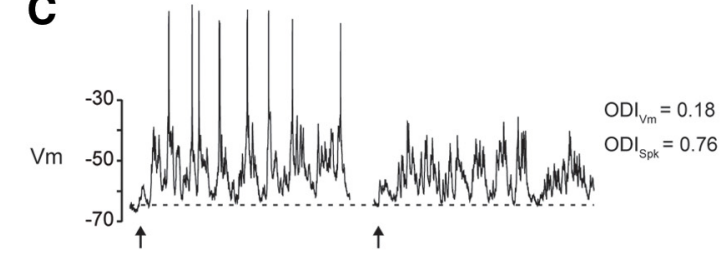

D

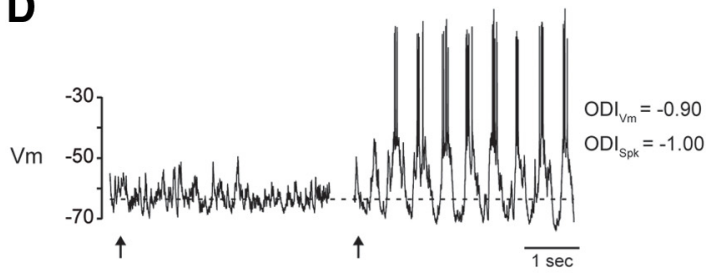

G

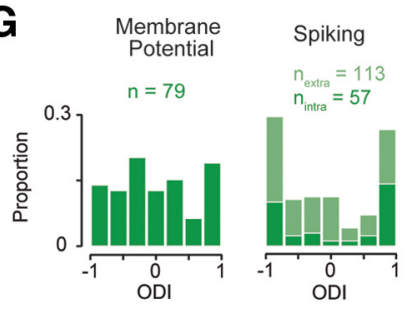

H

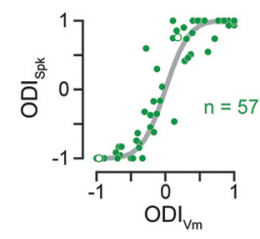

Figure 1. Strabismus alters ocular dominance of neurons in primary visual cortex. $\boldsymbol{A}$, Intracellular recording of a V1 neuron from a normal animal responding to a drifting grating of preferred orientation, spatial frequency, and spatial size presented independently to each eye. Arrows indicate stimulus onset time. Stimulation of either eye evoked subthreshold responses, but action potentials were evoked more for left eye stimulation. $\boldsymbol{B}$, Same as in $\boldsymbol{A}$ for a significantly binocular neuron. $\boldsymbol{C}$, Intracellular record from a V1 neuron in a strabismic animal. Strong subthreshold responses were evoked by both eyes, like in $\boldsymbol{A}$, however, action potentials were evoked only for dominant eye stimulation. $\boldsymbol{D}$, Example of a severely monocular neuron in $\mathrm{V} 1$ of a strabismic animal. $\boldsymbol{E}$, Ocular dominance distribution for all V1 neurons recorded in normal animals. Subthreshold membrane potential (left) is more binocular than for suprathreshold spiking activity (right). Spiking responses include intracellular (dark shading) and extracellular (light shading) records. $\boldsymbol{F}$, Relationship between membrane potential and spiking ocular dominance in V1 neurons from normal animals. $\boldsymbol{G}$, Same as in $\boldsymbol{E}$ for V1 neurons recorded in strabismic animals. Membrane potential ocular dominance is less binocular, and spiking activity shows dramatic monocularity. $\boldsymbol{H}$, Same as in $\boldsymbol{G}$ for strabismic animals. The relationship between subthreshold and suprathreshold ocular dominance is unaffected by an ocular misalignment. Curves were generated with typical power-law exponent ( $p=3$; see Materials and Methods; Priebe et al., 2004).

with a power law nonlinearity (Anderson et al., 2000b; Hansel and van Vreeswijk, 2002; Miller and Troyer, 2002; Priebe et al., 2004):

$$
R\left(V_{\mathrm{m}}\right)=k\left[\bar{V}_{\mathrm{m}}-V_{\text {rest }}\right]_{+}^{p},
$$

where $R$ is spike rate, $\bar{V}_{\mathrm{m}}$ is trial-averaged membrane potential, $V_{\text {rest }}$ is resting membrane potential, and the subscript + indicates rectification $\left(r=0\right.$ for $\left.V_{\mathrm{m}}<V_{\text {rest }}\right)$. The power law nonlinearity accounts for the effect of trial-to-trial variability by smoothing the threshold-linear relationship between mean membrane potential and mean spike rate (Anderson et al., 2000b).

Statistics. Mann-Whitney tests were two sided. Welch's $t$ tests were two sided and used only on distributions that were Gaussian, as judged by the Lilliefors test $(p>0.05)$.

\section{Results}

To characterize changes in synaptic input onto V1 neurons associated with strabismus during development, we obtained wholecell patch-clamp recordings in vivo (Pei et al., 1991; Ferster and Jagadeesh, 1992; Margrie et al., 2002) from cats after artificially inducing exotropic strabismus before the critical period of visual cortex development, and compared those with recordings from litter-matched control animals and normal animals (Hubel and Wiesel, 1965; Chino et al., 1983, 1994; see Materials and Methods).

\section{Ocular dominance of membrane potential and spike rate}

We first verified that our procedure for inducing an ocular misalignment produced the changes in V1 spike rate ocular domi- nance found previously (Hubel and Wiesel, 1965; Yinon and Auerbach, 1975; Chino et al., 1983, 1994; Freeman and Tsumoto, 1983; Kalil et al., 1984; Löwel et al., 1998; Engelmann et al., 2002), by obtaining extracellular recordings in the strabismic animals and their litter-matched controls. Dichoptic stimulus presentation was used to identify the dominant eye for each neuron, after which we then characterized orientation selectivity, spatial frequency tuning, and receptive field location (see Materials and Methods; Ohzawa and Freeman, 1986a,b).

We characterized the ocular dominance of subthreshold (membrane potential) and suprathreshold (spiking) responses in V1 neurons of normal and strabismic animals, using optimal drifting gratings presented to each eye separately (Fig. $1 A-D)$. We quantified ocular dominance profiles with an ocular dominance index (ODI):

$$
\text { ODI }=\frac{R_{\text {contra }}-R_{\text {ipsi }}}{R_{\text {contra }}+R_{\text {ipsi }}} \text {. }
$$

The ocular dominance index for spike rate $\left(\mathrm{ODI}_{\mathrm{spk}}\right)$ in normal animals, which includes data from both intracellular and extracellular recordings, is characterized by a uniform distribution (Fig. 1E, right). In strabismic animals, however, the ODI $\mathrm{spk}_{\mathrm{sis}}$ di tribution is peaked at high and low values, indicating markedly decreased binocularity, with many neurons spiking in response only to stimuli presented to one eye (Fig. $1 G$, right). The ODI $\mathrm{spk}_{\mathrm{sp}}$ distributions for normal and strabismic animals are similar to 
A
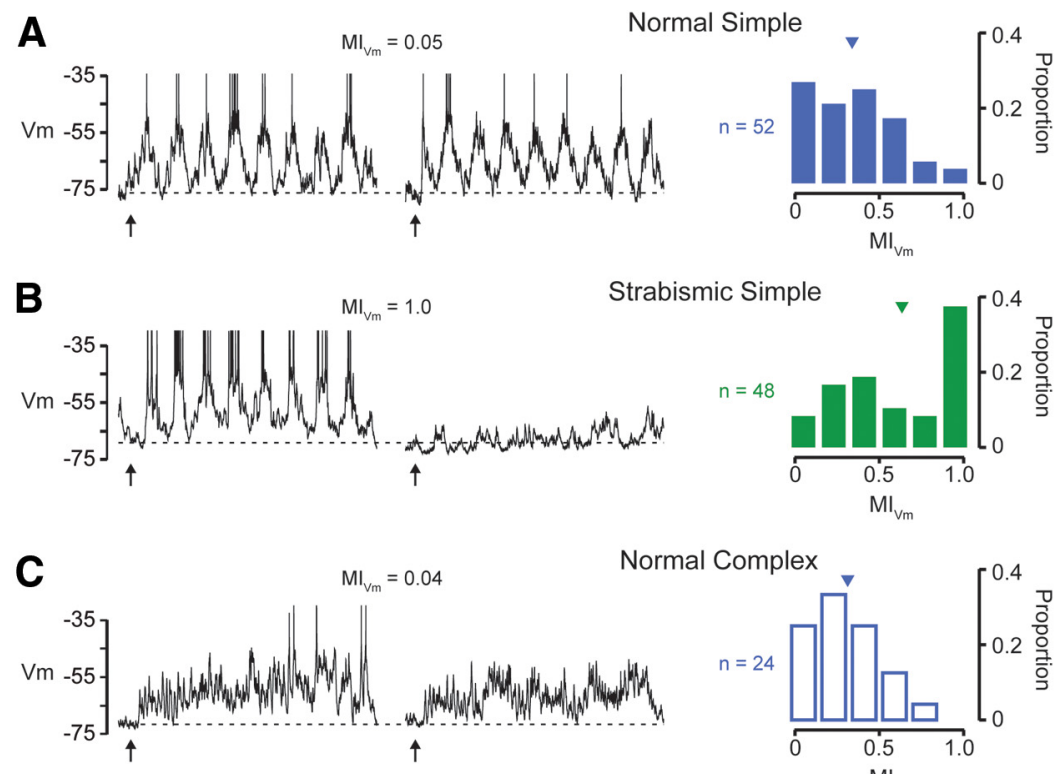

Normal Complex
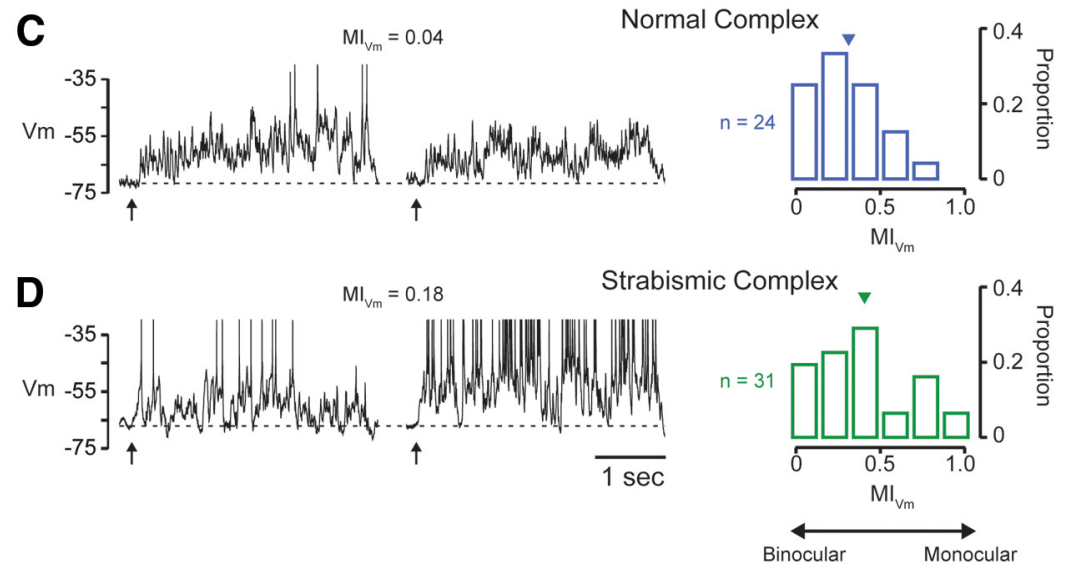

Figure 2. Monocularity of subthreshold input to simple and complex cells in primary visual cortex. $A$, Example of intracellular record from a V1 simple cell in the normal animal (left). Strong synaptic input evoked by stimulation of either eye, reflected in low MI values (absolute value of ocular dominance). Spikes have been truncated to visualize subthreshold input. Arrows indicate the beginning of grating stimulation. Distribution of membrane potential MI across all V1 simple cells in normal animals shows that most receive binocular synaptic input (right). Arrowheads indicate the median $\mathrm{MI}_{\mathrm{Vm}_{\mathrm{m}}} \boldsymbol{B}$, Example simple cell from a strabismic animal is severely monocular, similar to the example shown in Figure $1 D$. Simple cells from strabismic animals show dramatic increase in MI for subthreshold input (right). C, Example complex cell from V1 of a normal animal. Complex cells in normal animals receive binocular subthreshold input (right). $\boldsymbol{D}$, Example complex cell from a strabismic animal. Across the population, complex cells are slightly more monocular, but not to the degree found in simple cells, shown in $\boldsymbol{B}$.

those reported previously (Hubel and Wiesel, 1965; Chino et al., 1994).

A complete loss of spiking responses to stimulation of one eye indicates a loss of synaptic input from that eye, but latent inputs may persist that evoke only subthreshold responses. To uncover the extent of synaptic changes that occur in strabismic animals, we examined the ocular dominance of the membrane potential for individual V1 neurons. Membrane potential ocular dominance was different between strabismic and normal animals. The $\mathrm{ODI}_{\mathrm{Vm}}$ distribution was peaked at 0 in normal animals (Fig. 1E), but was flat in strabismic animals (Fig. $1 G$ ). The distribution of ocular dominance for membrane potential was also significantly different than that of the spike responses (Fig. $1 E, G$ ). In both normal and strabismic animals, membrane potential responses were more binocular than spike rate, as shown by the increased number of neurons with $\mathrm{ODI}_{\mathrm{Vm}}$ values near 0 relative to $\mathrm{ODI}_{\mathrm{spk}}$. The membrane potential records thus indicate that a total loss in spiking responses to stimulation of one eye is undergirded by only a partial loss of synaptic input.

Apart from changes in synaptic input, additional factors such as differences in intrinsic properties could play a role in the spike rate ocular dominance shift caused by strabismus. We did not, however, find a statistically significant change in the resting membrane potential between V1 neurons in normal and strabis- mic animals (normal, $V_{\text {rest }}=-61.6 \pm 9.7$ $\mathrm{mV}, n=76$; strabismic, $V_{\text {rest }}=-60.7 \pm$ $8.6 \mathrm{mV}, n=79$; mean $\pm \mathrm{SD}, p>0.30$, Welch's $t$ test). We also measured the nonlinear relationship between membrane potential and spike rate using a power-law fit (Priebe et al., 2004) for intracellular records with sufficient spiking activity (see Materials and Methods) and did not find a difference in the fit exponent between V1 neurons in normal and strabismic animals (normal, $p=3.0 \pm 0.9, n=52$; strabismic, $p=2.9 \pm 1.2, n=57$; mean $\pm \mathrm{SD}, p>$ 0.25 , Welch's $t$ test). The relationships between $\mathrm{ODI}_{\mathrm{Vm}}$ and $\mathrm{ODI}_{\mathrm{spk}}$ in normal and strabismic animals were also similar, consistent with the transformation of membrane potential into spike rate being unaffected by strabismus (Fig. $1 F, H$; Priebe and Ferster, 2008; Priebe, 2008). Differences in ocular dominance between normal and strabismic animals thus depend mainly on changes in synaptic input.

Because the ODI distributions are approximately symmetric around 0 in normal and strabismic animals (Fig. $1 E, G$ ), it is also convenient to use a monocularity index (MI), defined as the absolute value of ODI. The MI is 0 when equal responses are elicited from both eyes; the MI is 1 when responses are evoked by only one eye. We found that membrane potential was more binocular in normal (mean $\left.\mathrm{MI}_{\mathrm{Vm}}, 0.33 \pm 0.24 \mathrm{SD} ; n=76\right)$ than in strabismic animals (mean $\mathrm{MI}_{\mathrm{Vm}}, 0.64 \pm$ $0.34 \mathrm{SD} ; n=79$; mean $\pm \mathrm{SD} ; p<0.001$, Mann-Whitney test). The same trend was evident in spike rate from extracellular records and intracellular records with spikes (normal $\mathrm{MI}_{\mathrm{spk}}, 0.53 \pm 0.35, n=$ 121; strabismic $\mathrm{MI}_{\mathrm{spk}}, 0.68 \pm 0.33, n=170$; mean $\pm \mathrm{SD} ; p<$ 0.001 , Mann-Whitney test). Because normal animals included litter-matched sham controls and non-litter-matched, nonsham animals, we compared MI from spiking records from extracellular records and intracellular records with spikes in each group; we found no statistical difference (mean $\mathrm{MI}_{\text {spk}}$, $0.48 \pm 0.36 \mathrm{SD}, n=56$; mean $\mathrm{MI}_{\text {spk }}, 0.57 \pm 0.34 \mathrm{SD}, n=65$; $p=0.14$, Mann-Whitney test).

Strikingly, the increase in monocularity due to strabismus depended on neuron type. Simple cells are primarily found in layer 4 of V1, receive direct input from the lateral geniculate nucleus, and modulate in response to drifting gratings (Fig. 2 A, B; Skottun et al., 1991; Hirsch et al., 1998; Priebe et al., 2004; Martinez et al., 2005). Simple cells in strabismic animals exhibited a large increase in membrane potential monocularity (normal $\mathrm{MI}_{\mathrm{Vm}}$, $0.35 \pm 0.25, n=52$; strabismic $\mathrm{MI}_{\mathrm{Vm}}, 0.62 \pm 0.33, n=48$; mean $\pm \mathrm{SD} ; p<0.001$, Mann-Whitney test). In contrast, complex cells, which are typically found in superficial and deep layers of $\mathrm{V} 1$ and have stimulus-evoked responses that are dominated by an unmodulating component (Fig. 2C,D), exhibited only slight changes in membrane potential ocular dominance (normal, 
$\mathrm{MI}_{\mathrm{Vm}}, 0.30 \pm 0.20, n=24 ;$ strabismic, $\mathrm{MI}_{\mathrm{Vm}}, 0.40 \pm 0.27, n=$ 31; mean $\pm \mathrm{SD} ; p=0.17$, Mann-Whitney test).

A difference in monocularity between simple and complex cells was also seen in spike rate. Spike rate monocularity shifts were larger in simple cells across extracellular records and intracellular records with spikes (normal, $\mathrm{MI}_{\mathrm{spk}}, 0.62 \pm 0.34, n=70$; strabismic, $\mathrm{MI}_{\mathrm{spk}}, 0.83 \pm 0.26, n=84$; mean $\pm \mathrm{SD} ; p<0.001$, Mann-Whitney test) than in complex cells (normal, $\mathrm{MI}_{\text {spk }}$, $0.41 \pm 0.33, n=51$; strabismic, $\mathrm{MI}_{\mathrm{spk}}, 0.54 \pm 0.33, n=86$; mean $\pm \mathrm{SD} ; p=0.028$, Mann-Whitney test), which was also observed previously (Chino et al., 1988, 1994). We detected a monocularity shift in the spike responses, but not the membrane potential responses of complex cells, because the nonlinearity relating spike rate and membrane potential acts to enhance small differences in membrane potential responses (Priebe and Ferster, 2008; Priebe, 2008; Fig. $1 F, H)$. Our measurements of spiking responses from intracellular and extracellular records corroborate previous reports that complex cell spiking responses are more binocular than those of simple cells in both normal and strabismic cat V1 ( $p=0.002$ and $p=0.001$, respectively; MannWhitney test; Chino et al., 1988, 1994). Heightened binocularity in complex cells might account for the more subtle change in spiking monocularity we observed. Nonetheless, a clear loss of binocular spiking responses in complex cells is evident in strabismic animals, while binocularity of subthreshold inputs remains unchanged (Fig. 2). Simple cells receive most of their input from the thalamus, but complex cells receive input mainly from other cortical neurons (Ferster et al., 1996; Chung and Ferster, 1998). Accordingly, the dramatic increase in simple cell monocularity apparent in membrane potential responses and the subtle change in complex cell monocularity apparent only in spike rate are consistent with strabismus driving synaptic plasticity primarily at thalamocortical synapses.

These results indicate that a dramatic increase in the monocularity of simple cells accompanies strabismus. This enhanced monocularity, however, is not accompanied by a hyperpolarization elicited by stimulation of the nonpreferred eye. Across monocular simple and complex cells $\left(\mathrm{MI}_{\mathrm{Vm}}>0.75\right)$ the mean cycle-averaged response to the nonpreferred eye was $-0.17 \pm 1.20 \mathrm{mV}$ (mean $\pm \mathrm{SD}$ ), and in only 7 of 24 neurons were responses significantly hyperpolarized relative to the resting membrane potential (bootstrap analysis; Sokal and Rohlf, 1995). Since these values are near zero, membrane potential responses are very near rest during blank periods and constitute effectively no sensory response. Therefore it does not appear that strabismus induces an inhibitory antagonism between neurons selective for the opposite eyes.

Our measurements of peak responses are calculated after removing the response to the first stimulus cycle, as we attempted to analyze steady-state responses and ascertain receptive field properties. It is possible, however, that the initial transient component of neuron response conveys important visual information (Celebrini et al., 1993; Gawne et al., 1996; Müller et al., 2001; Reich et al., 2001; Frazor et al., 2004; Palmer et al., 2007; Chen et al., 2008; Shriki et al., 2012). We examined whether including the first response cycle or using only the first response cycle changed our MI measurements, particularly in complex cells that are phase insensitive. Across all measurements of membrane potential and spiking responses in both simple and complex cells from either control or strabismic animals, inclusion of the first cycle did not significantly change measurements of $\mathrm{MI}(p>0.40$, Mann-Whitney test). Using only the first response cycle also did not alter MI across all records ( $p>0.10$, Mann-Whitney test).

An additional factor that may bias our results is the side of the brain recorded from relative to the deviated eye. The majority of our records are from the left hemisphere, the side contralateral to the deviated eye, but we obtained records from both hemispheres. In both hemispheres, a bimodal distribution of ODI was present for spike rate (Hartigan's dip test, $p<0.05$ ). The monocular indices for both the right and left hemispheres of strabismic animals were significantly higher than the monocular indices in normal animals, but the indices between left and right hemispheres were not significantly different from one another (median $\mathrm{MI}_{\text {spk }}, 0.68$ and 0.82 , respectively; rank-sum test). Because we find no significant differences in ocular dominance patterns between hemispheres, the data from both hemispheres have been grouped together.

\section{Binocular integration and disparity selectivity}

Thus far we have only described V1 neuron responses to stimuli presented separately to each eye, but normally V1 neurons integrate binocular signals to extract information about the depth of objects in the world (Ohzawa et al., 1990; DeAngelis et al., 1991; Cumming and Parker, 1997; Cumming and DeAngelis, 2001). In normal animals, V1 neurons signal object depth through their selectivity for disparity, the spatial difference between right and left eye images. To determine how strabismus alters this binocular integration, we measured disparity selectivity by systematically varying the phase difference between drifting gratings presented dichoptically (Ohzawa and Freeman, 1986a,b).

In normal animals, simple cells show membrane potential and spiking responses that depend on stimulus disparity. In cycleaveraged responses from an example neuron (Fig. $3 A$ ), the preferred disparity $\left(270^{\circ}\right.$ phase difference) evoked large membrane potential fluctuations, while the null disparity $\left(90^{\circ}\right.$ phase difference) evoked little change in membrane potential. A similar pattern of disparity selectivity was observed in the spike rate of neurons (Fig. $3 A$ ). The large fluctuations at the preferred disparity suggest a phase alignment of ocular inputs. Plotting peak subthreshold and suprathreshold responses (F1 + DC; see Materials and Methods) shows response modulation by binocular phase differences and binocular responses that were much stronger than the response to either eye alone (Fig. $3 A$, bottom). To quantify response selectivity for binocular phase difference, we computed a disparity selectivity index (DSI; Swindale, 1998; Ringach et al., 2002; Scholl et al., 2013):

$$
\text { DSI }=\frac{\sqrt{\left(\sum_{\phi} R_{\phi} \sin \phi\right)^{2}+\left(\sum_{\phi} R_{\phi} \cos \phi\right)^{2}}}{\sum_{\phi} R_{\phi}} .
$$

Although membrane potential was tuned to similar disparities as spiking responses in normal animals, DSI values were greater for spike rate than membrane potential $\left(\mathrm{DSI}_{\mathrm{Vm}}, 0.18\right.$; $\mathrm{DSI}_{\mathrm{spk}}, 0.46$; Fig. 3A, bottom). This difference is a consequence of the membrane potential-to-spike rate transformation that has also been shown to enhance orientation tuning, direction selectivity, and ocular dominance (Priebe and Ferster, 2008).

Simple cells in strabismic animals exhibited a loss of disparity selectivity in membrane potential and spike rate. There was a lack of disparity tuning (Fig. 3B; DSI $_{\mathrm{Vm}}, 0.05$ DSI $_{\mathrm{spk}}, 0.07$ ) even in the few simple cells that maintained binocular membrane potential responses (Fig. $3 B ; \mathrm{MI}_{\mathrm{Vm}}, 0.37 ; \mathrm{MI}_{\mathrm{spk}}, 0.52$ ). In addition, most binocular responses for membrane potential and spike rate were smaller than responses to stimulation of the preferred eye. Across all simple cell intracellular records from strabismic and normal 

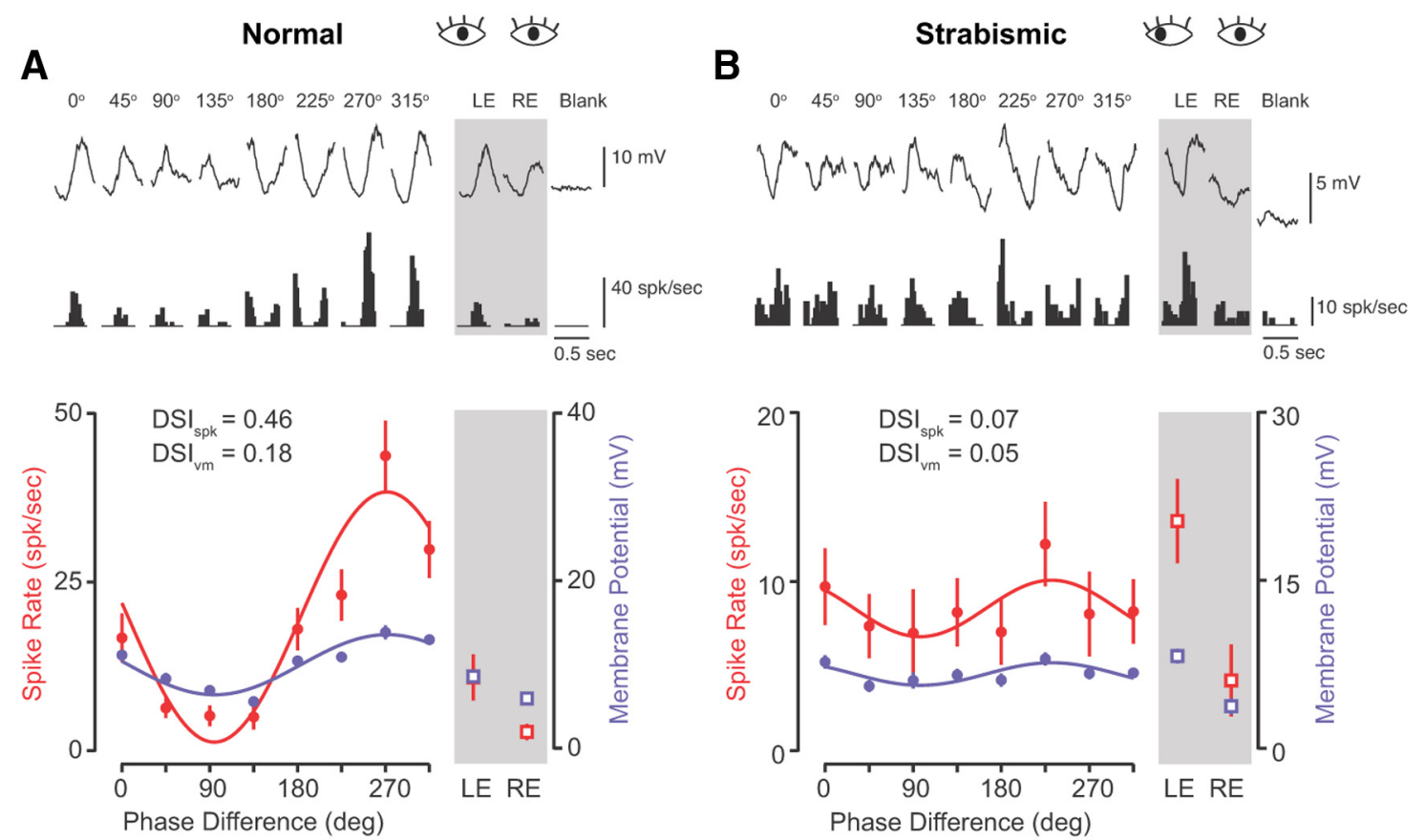

C
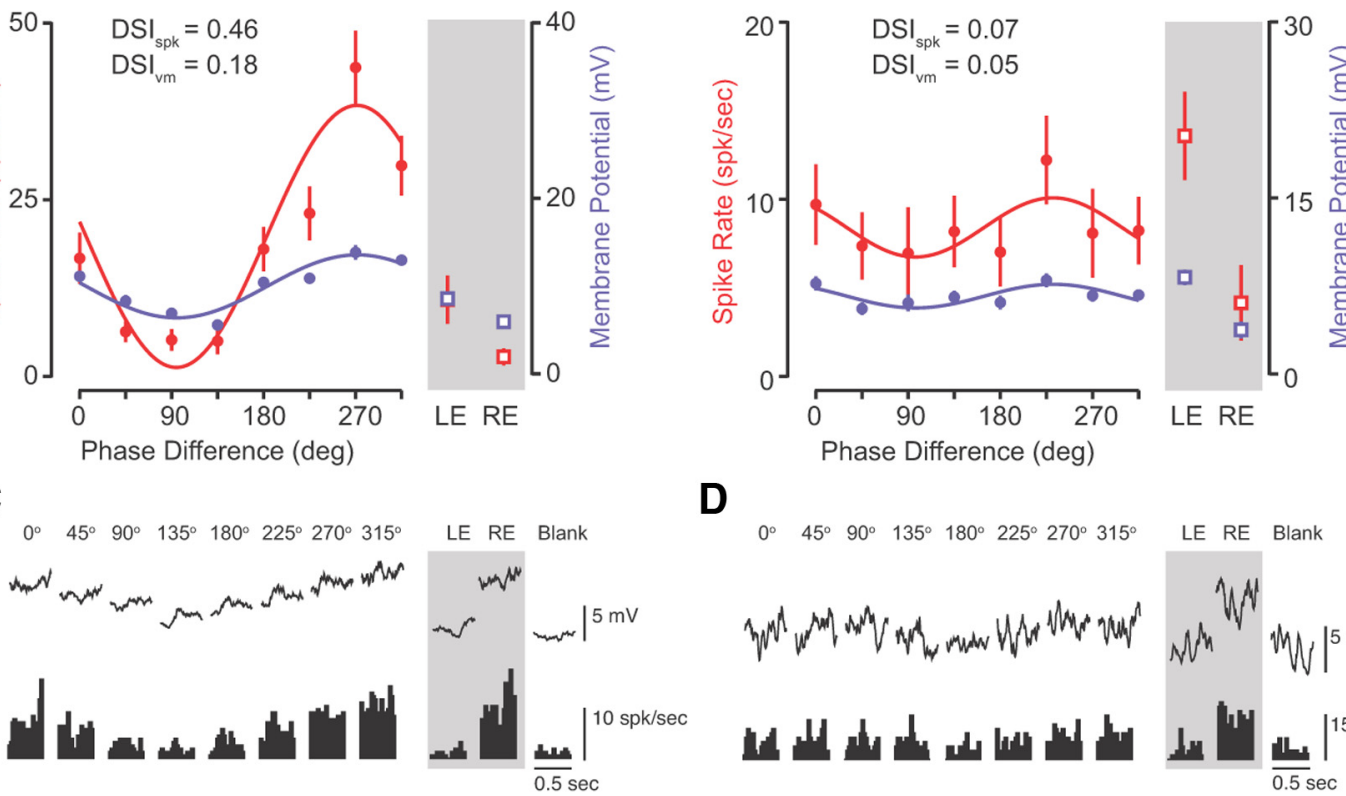

D
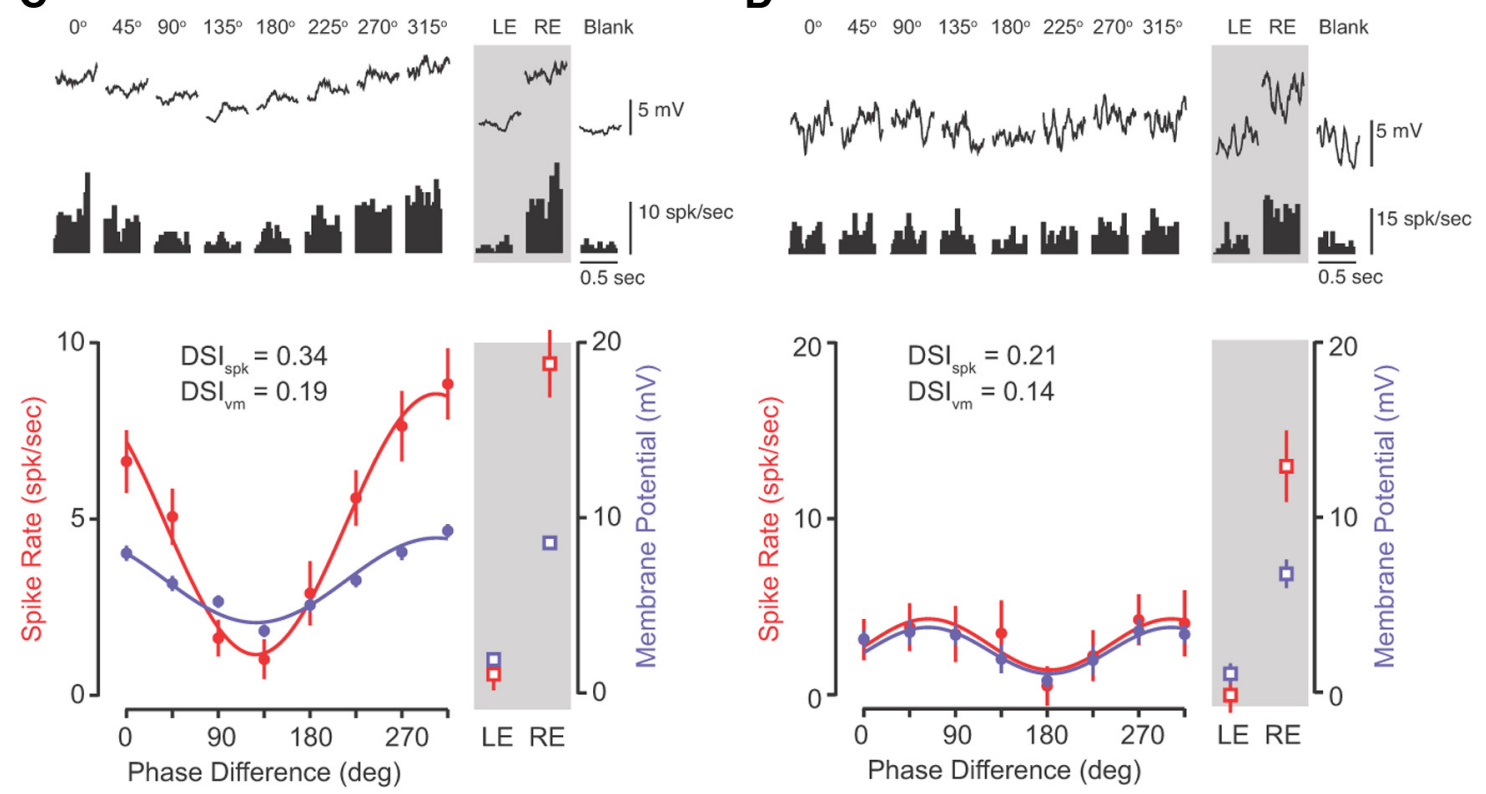

Figure 3. Binocular disparity selectivity of membrane potential and spiking responses in primary visual cortex. $A$, Simple cell cycle-averaged responses to a random sequence of eight binocular phase combinations of optimal drifting gratings presented dichoptically (top), shown for subthreshold membrane potential and evoked spiking responses. Binocular stimuli were interleaved with monocular stimulation (gray shading) and a blank (mean-luminance) period. This example simple cell has a preferred binocular phase difference of $270^{\circ}$, evident in the large membrane potential fluctuations and strong modulation of spiking responses. Responses at the preferred disparity can be larger than responses from the stimulation of either eye alone, particularly for evoked spiking activity. Little response was evoked at the null phase $\left(90^{\circ}\right)$. The full extent of disparity tuning plotted for membrane potential (purple) and spiking (red) peak responses (F1 + DC; bottom) is shown. The mean and SE are shown for binocular (circles) and monocular (squares) conditions. Solid curves are sine-wave fits used to illustrate disparity tuning. Strong modulation of peak responses by different disparities is reported by a vector strength index (DSI). B. Same as in $\boldsymbol{A}$ for simple cell recorded in a strabismic animal. Despite strong membrane potential fluctuations and spiking responses evoked by stimulation of either eye (gray), simple cells were not disparity tuned. Peak responses plotted across all disparities also show suppression in during binocular stimulus conditions (bottom). C, Same as in $\boldsymbol{A}$ for an example complex cell. D, Same as in $\boldsymbol{B}$ for a complex cell. Binocular suppression and lack of disparity tuning in membrane potential and spiking responses is evident for both cycle-averaged responses and tuning curves. LE, Left eye; $R E$, right eye.

animals, we found a systematic decrease of DSI in membrane potential and spiking responses (Fig. $4 A$ ). DSI values for membrane potential were modest (normal, $\mathrm{DSI}_{\mathrm{Vm}}, 0.12 \pm 0.08, n=$ 52 ; strabismic, $\mathrm{DSI}_{\mathrm{Vm}}, 0.09 \pm 0.08, n=48$; mean $\left.\pm \mathrm{SD}\right)$, but the decrease in DSI was statistically significant $(p=0.05$, MannWhitney test). A decrease in disparity sensitivity was also evident in spiking responses across extracellular and spiking-intracellular

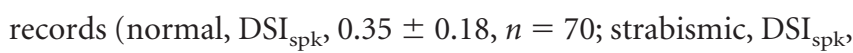
$0.24 \pm 0.18, n=84$; mean \pm SD; $p<0.001$, Mann-Whitney test).

Similar changes in disparity selectivity were observed in V1 complex cells. In normal animals, complex cell membrane potential and spike rate responses were disparity selective. In an example neuron (Fig. $3 C$ ), few membrane potential modulations are evident compared to simple cells. Instead, large DC (mean) de- 
A Simple

Membrane Potential
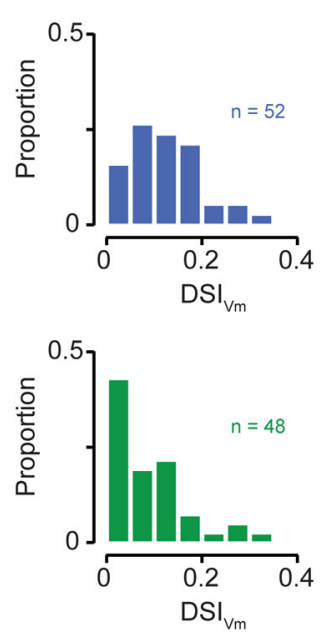

C
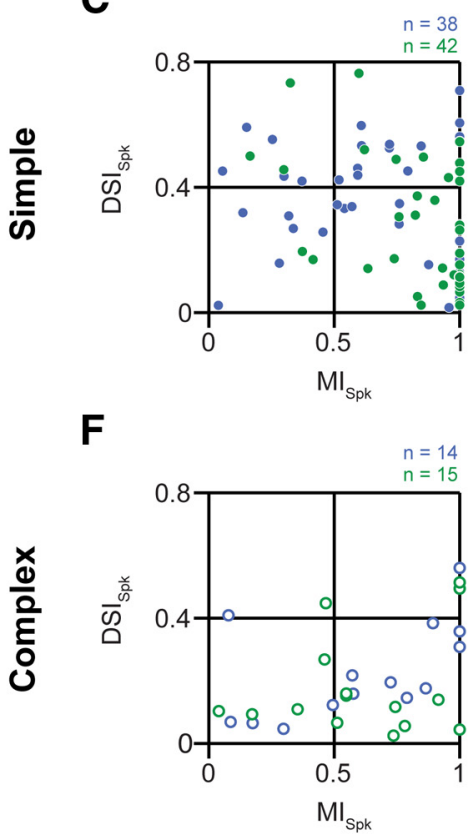

Spiking

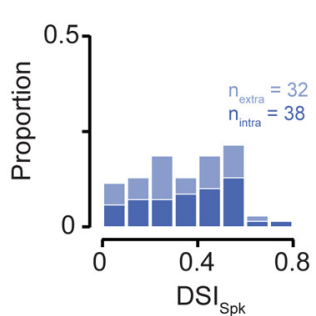

B Complex

Membrane Potential
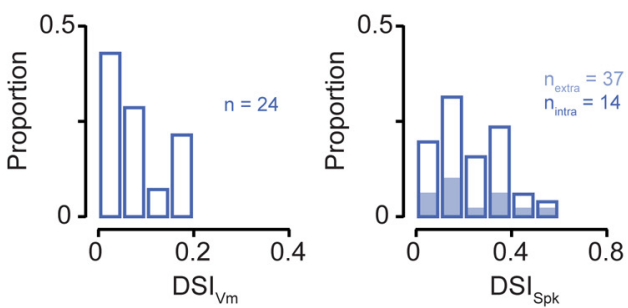

Strabismic 当造
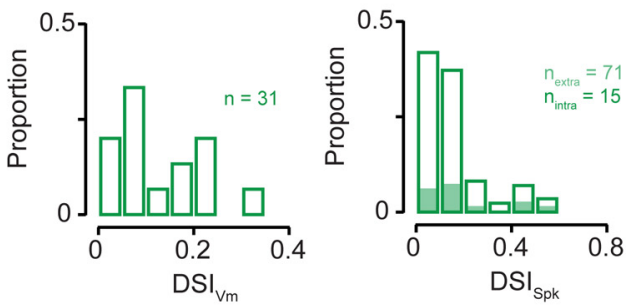

E
D

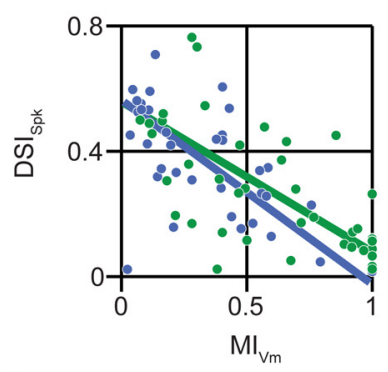

G

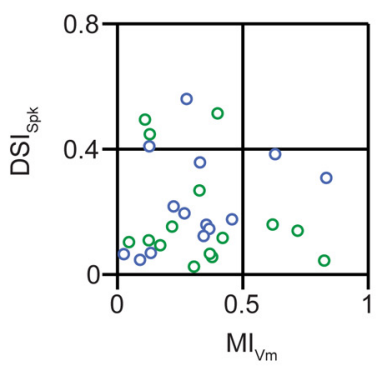

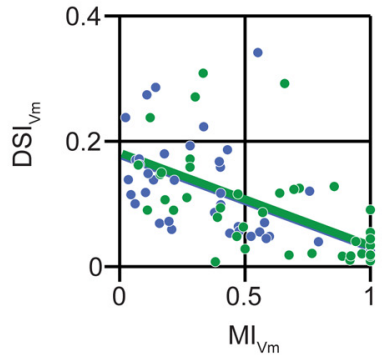

H

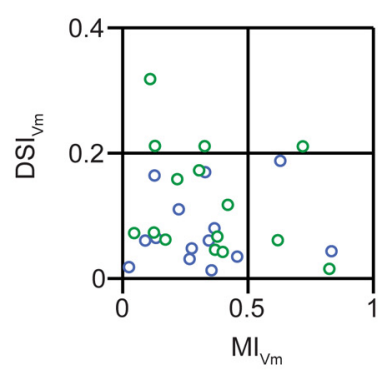

Figure 4. Effect of strabismus on disparity selectivity. $A$, Distributions of DSI values for simple cell subthreshold membrane potential and suprathreshold spiking responses in normal (blue) and strabismic (green) animals. Spiking responses include intracellular (dark shading) and extracellular (light shading) records. B, Same as in A for complex cells. C, Relationship between spiking MI (absolute value of ocular dominance) and spiking DSI in simple cells from normal and strabismic animals. D, Same as in ( for subthreshold Ml and spiking DSI. E, Same as in C for subthreshold MI and subthreshold DSI. $\boldsymbol{F}$, Same as in $\boldsymbol{C}$ for complex cells. $\boldsymbol{G}$, Same as in $\boldsymbol{D}$ for complex cells. $\boldsymbol{H}$, Same as in $\boldsymbol{E}$ for complex cells.

polarizations shape disparity preference and underlie selectivity observed in spiking responses. For example, the membrane potential at the null phase $\left(135^{\circ}\right)$ is only slightly larger than the nonpreferred eye $(\sim 4 \mathrm{mV})$, while at the preferred phase $\left(315^{\circ}\right)$ the subthreshold response is much larger $(\sim 10 \mathrm{mV})$. As with simple cells, the preferred disparity of membrane potential and spike rate were matched, but the disparity selectivity was greater for spike rate $\left(\mathrm{DSI}_{\mathrm{Vm}}, 0.19\right.$; $\left.\mathrm{DSI}_{\mathrm{spk}}, 0.34\right)$. Complex cells from strabismic animals, like simple cells, were weakly disparity selective (Fig. 3D). Across all complex cell records, strabismus caused a large decrease in spike rate disparity selectivity (normal, DSI ${ }_{\mathrm{spk}}$, $0.23 \pm 0.14, n=51$; strabismic, DSI $_{\text {spk }}, 0.15 \pm 0.13, n=86$; mean \pm SD; $p<0.001$, Mann-Whitney test; Fig. $4 B$ ). There was, however, no significant difference in $\mathrm{DSI}_{\mathrm{Vm}}$ (normal, $\mathrm{DSI}_{\mathrm{Vm}}$,
$0.08 \pm 0.06, n=24 ;$ strabismic, $\mathrm{DSI}_{\mathrm{Vm}}, 0.12 \pm 0.09, n=31$; mean $\pm \mathrm{SD} ; p=0.16$, Mann-Whitney test; Fig. $4 B$ ).

Since we removed responses to the first stimulus cycle, which could potentially contain important sensory information in complex cells, which are phase insensitive, we also examined DSI in responses to the first stimulus cycle. Similar to measurements of MI, this did not change our results for subthreshold or suprathreshold responses. Complex cells from normal animals were significantly more selective for disparity than those from strabismic animals (median DSI, 0.22 and 0.15 , respectively; $p=0.02$, Mann-Whitney test). Although DSI values were higher for membrane potential, there was, again, no difference between normal and strabismic animals (median DSI, 0.13 and 0.16 , respectively; $p=0.20$, Mann-Whitney test). 


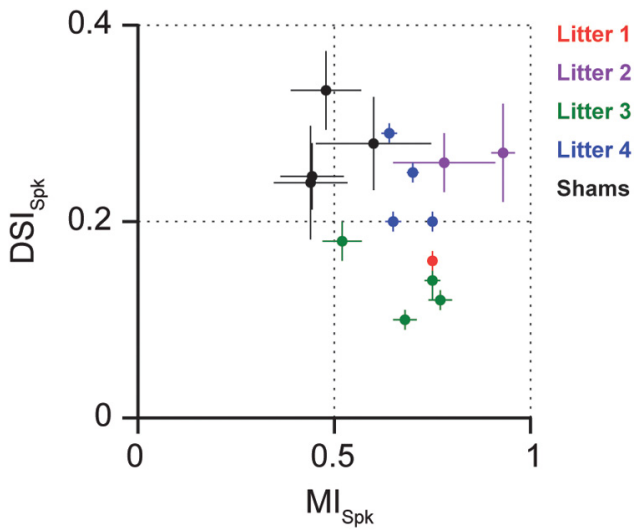

Figure 5. Comparison of spiking monocularity and disparity selectivity across animal litters. Mean and SE of monocularity and binocular disparity selectivity from spiking responses of neurons recorded in each animal from each litter are shown. Strabismic animals are color coded by litter. Sham control animals shown in black.

Response suppression by binocular stimulation, relative to the response to monocular stimulation, was evident in many records (Fig. $3 B, D$ ) and will be discussed in detail below. This suppression suggests that factors aside from a mismatch of excitatory inputs from each eye are involved in the changes to cortical circuitry associated with strabismus (Levi et al., 1979; Sengpiel and Blakemore, 1994; Sengpiel et al., 1994, 2006; Fig. 4A,B).

We have thus far described mainly the average effects of strabismus. There was, however, considerable diversity in the effects of our procedure for inducing strabismus on the degree of monocularity and disparity in different animals. The range of DSI values observed $(0-0.75)$ was similar between normal and strabismic animals (Fig. 4A,B). Although MI and DSI values calculated for each animal overlapped for strabismic and control animals, when MI and DSI were considered separately, there was minimal overlap when both MI and DSI were jointly considered (Fig. 5). In each litter there were at least several strabismic animals with large differences in MI and DSI from control animals, indicating that the within-litter variability was as large as that across litters. We do not know if the variability was due to differences in our procedure for inducing strabismus or to variability in environmental and genetic factors.

We have focused on the degree of binocular selectivity in normal and strabismic animals, but strabismus could also alter the response amplitude of neurons. We therefore examined the peak spiking activity and membrane potential responses from records in each population. In normal animals, spiking responses to the preferred binocular stimulus were greater than to the preferred eye in simple cells $(20.2 \pm 21.4$ spikes/s and $14.9 \pm 2.0 \mathrm{spikes} / \mathrm{s}$, respectively; $n=70$; mean $\pm \mathrm{SD} ; p=0.05$, Mann-Whitney test). This trend was not significant for complex cells (binocular, $15.8 \pm 17.1$ spikes/s; monocular, $12.4 \pm 4.7$ spikes/s; $n=51$; mean $\pm \mathrm{SD} ; p=0.40$, Mann-Whitney test); however, membrane potential responses at the preferred binocular phase for complex cells were significantly larger than those evoked by the preferred eye $(7.8 \pm 2.8 \mathrm{mV}$ and $6.5 \pm 9.3 \mathrm{mV}$, respectively; $n=24$; mean $\pm \mathrm{SD} ; p=0.05$, Mann-Whitney test). Simple cell subthreshold responses showed a similar trend (binocular, $10.3 \pm$ $4.8 \mathrm{mV}$; monocular, $9.2 \pm 4.7 \mathrm{mV} ; n=52$; mean $\pm \mathrm{SD} ; p=0.29$, Mann-Whitney test). In contrast to normal animals, suprathreshold and subthreshold records from strabismic animals showed no differences in both simple (spikes, binocular, 17.6 \pm 16.7 spikes/s; monocular, $17.9 \pm 7.1$ spikes/s; $n=84$; mean $\pm \mathrm{SD} ; p=$
0.86, Mann-Whitney test; membrane potential, binocular, $10.7 \pm$ $5.5 \mathrm{mV}$; monocular, $10.5 \pm 5.4 \mathrm{mV} ; n=48$; mean $\pm \mathrm{SD} ; p=0.75$, Mann-Whitney test) and complex cells (spikes, binocular, $11.4 \pm$ 13.1 spikes/s; monocular, $11.8 \pm 12.1$ spikes $/ \mathrm{s} ; n=86 ;$ mean $\pm \mathrm{SD}$; $p=0.87$, Mann-Whitney test; membrane potential, binocular, $6.7 \pm 4.4 \mathrm{mV}$; monocular, $6.5 \pm 4.3 \mathrm{mV} ; n=31$; mean $\pm \mathrm{SD} ; p=$ 0.70 , Mann-Whitney test). The increase in peak binocular responses in normal animals, but not strabismic animals, is expected given the loss of disparity selectivity and evidence for binocular response suppression.

\section{Relationship between ocular dominance and disparity selectivity}

Strabismus alters both ocular dominance and disparity selectivity, but it is not clear whether a single mechanism can account for these changes. Establishing a link between disparity selectivity and ocular dominance has remained difficult (LeVay and Voigt, 1988; Chino et al., 1994; Read and Cumming, 2004), suggesting that these two changes may reflect multiple circuit changes. On the other hand, for a neuron to be disparity selective, it must receive input from both eyes. This requirement was insufficient to enforce a relationship between spiking ocular dominance and spiking disparity selectivity (Fig. 4C,F) for V1 neurons recorded in either normal or strabismic animals [mean principal component analysis (PCA) slope, normal, $0.06 \pm 0.13$; strabismic, $-0.20 \pm 0.23$; bootstrapped SE].

However, a relationship between monocularity and disparity selectivity at the level of synaptic input can be obscured by the threshold nonlinearity (Priebe and Ferster, 2008). We therefore compared membrane potential monocularity $\left(\mathrm{MI}_{\mathrm{Vm}}\right)$ to disparity selectivity based on spiking ( $\mathrm{DSI}_{\text {spk }}$ ) and membrane potential responses $\left(\mathrm{DSI}_{\mathrm{Vm}}\right)$. Simple cells from normal animals showed a significant correlation between $\mathrm{MI}_{\mathrm{Vm}}$ and $\mathrm{DSI}_{\mathrm{spk}}$ (mean PCA slope, $-0.59 \pm 0.09 ; n=38$; bootstrapped $\mathrm{SE}$ ), and $\mathrm{MI}_{\mathrm{Vm}}$ and $\mathrm{DSI}_{\mathrm{Vm}}$ (mean PCA slope, $-0.15 \pm 0.04$; bootstrapped SE; Fig. $4 D, E$, blue). These correlations demonstrate that disparity selectivity in simple cells depends strongly on the amount of binocular synaptic input a neuron receives.

Surprisingly, these trends were also found in strabismic animals (Fig. 4C-E, green). Simple cells in strabismic animals showed a significant correlation between $\mathrm{MI}_{\mathrm{Vm}}$ and DSI $\mathrm{spk}_{\text {(mean }}$ PCA slope, $-0.48 \pm 0.08 ; n=42$; bootstrapped SE) and $\mathrm{MI}_{\mathrm{Vm}}$ and $D_{S I}$ (mean PCA slope, $-0.15 \pm 0.03$; bootstrapped SE). In contrast, complex cells showed no significant relationship between subthreshold input and disparity sensitivity in either strabismic or normal animals (Fig. $4 F-H)$ ). The relationships between $\mathrm{DSI}_{\mathrm{Vm}}$ and $\mathrm{DSI}_{\mathrm{spk}}$ in normal and strabismic animals were similar (Fig. 6), consistent with differences between normal and strabismic animals being driven by changes in synaptic input.

The similar relationship between monocularity and disparity tuning for normal and strabismic animals suggests that simple cells in strabismic animals have the potential to be disparity selective if provided with substantial binocular input. The link we established between disparity selectivity and monocularity indicates that the same mechanism could account for the changes in both response properties of simple cells, and is consistent with plasticity of simple cell inputs occurring mainly at thalamocortical synapses, with remaining binocular inputs generating disparity selectivity in the expected manner.

\section{Suppression of binocular responses and synaptic inhibition} We frequently observed response suppression during binocular stimulation in records from strabismic animals. Suppression was 


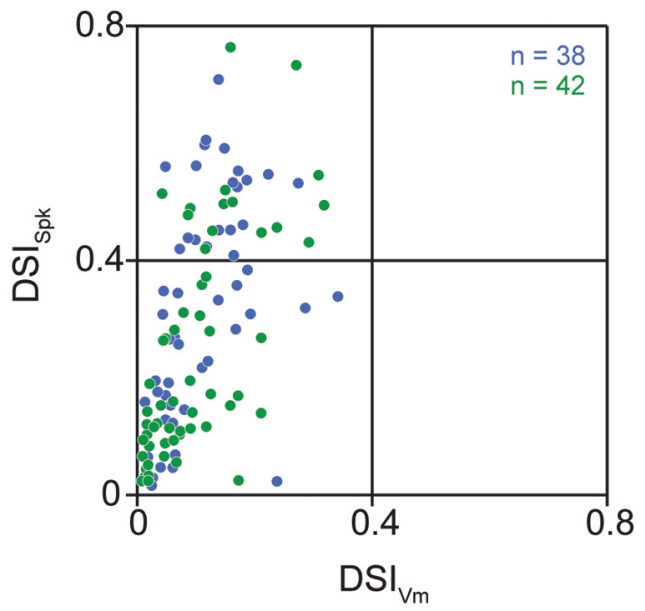

Figure 6. Relationship between subthreshold and suprathreshold disparity selectivity. The DSl is plotted for membrane potential and spiking responses in neurons from normal (blue) and strabismic (green) animals.

evident both in neurons that received binocular synaptic input (Fig. 3B) and in those that were monocular (Fig. 3D), indicating not only a disruption of binocular integration, but a possible neural mechanism for quenching binocular information in visual cortex. To quantify suppression, we measured binocular response Gain:

$$
\text { Gain }=\log _{10}\left(\frac{F_{\text {binoc }}^{0}+F_{\text {binoc }}^{1}}{R_{\text {pref }}}\right) .
$$

Gain is defined as a logarithmic ratio of the sum of disparity tuning mean and modulation divided by the peak response to the preferred eye (see Materials and Methods). Gain $<0$ indicates that the peak binocular response is less than the response to preferred eye stimulation alone. Gain $>0$ indicates binocular responses are greater than the preferred monocular response.

Many V1 simple and complex cells from normal animals have binocular membrane potential and spike rate responses that are greater than those evoked by stimulation of either eye alone (Fig. $7 A, B$ ). These correspond to large gain values (Fig. $7 A$; gain $_{\mathrm{Vm}}$, +0.28 ; $\left._{\text {gain }_{\text {spk }}},+0.81\right)$. In contrast, neurons from strabismic animals had binocular responses smaller than those evoked by the preferred eye (Fig. 7C,D; gain $_{\mathrm{Vm}},-0.09$; gain $_{\text {spk }},-0.23$ ). Simple and complex cells exhibiting subthreshold and suprathreshold binocular suppression (gain $<0$ ) were more prevalent in strabismic animals than in normal animals (Fig. 7 E, F). The proportion of simple cells displaying binocularly suppressed membrane potential and spike rate responses was larger in strabismic animals (membrane potential strabismic, 40\%; normal, 25\%; spike rate strabismic, 37\%; normal, 19\%). For complex cells, the proportion of neurons demonstrating suppression was also more pronounced in strabismic animals (membrane potential strabismic, 45\%; normal, 10\%; spike rate strabismic, 47\%; normal, $22 \%$ ).

Increased binocular suppression caused by strabismus was also reflected in average gain values for subthreshold responses in simple and complex cells (Fig. $7 E, G$ ) that were smaller in strabismic animals (simple strabismic, $0.02 \pm 0.10, n=48$; normal, $0.10 \pm 0.12, n=52$; mean $\pm \mathrm{SD}, p=0.004$; complex strabismic, $0.06 \pm 0.15, n=31$; normal, $0.08 \pm 0.08, n=24$; mean $\pm \mathrm{SD}, p=$ 0.10 ; Mann-Whitney test). Average gain values for spiking responses from extracellular records and intracellular records with spikes were also smaller in strabismic animals (Fig. $7 F, H$; simple strabismic, $0.12 \pm 0.26, n=84$; normal, $0.32 \pm 0.38, n=70$; mean $\pm \mathrm{SD}, p=0.001$; complex strabismic, $0.06 \pm 0.26, n=86$; normal, $0.23 \pm 0.35, n=51$; mean $\pm \mathrm{SD}, p=0.001$, MannWhitney test).

Given a clear increase in binocular suppression, we asked whether these neurons showed antagonism between the two eyes that may be revealed by monocular stimulation. Similar to the increased monocularity induced by strabismus, binocular suppression was not accompanied by hyperpolarization evoked by the nonpreferred eye. Suppressed neurons from strabismic animals $\left(\right.$ gain $_{V \mathrm{~m}}<0$ ) had small depolarizing responses from stimulation of the nonpreferred eye (mean, $1.5 \pm 2.3 \mathrm{mV}, \mathrm{SD}$; $n=32$ ). However, simple and complex cell responses were different. Simple cells with binocular suppression had nonpreferred eye responses which were much closer to spontaneous activity, and less than that of complex cells (simple, $0.96 \pm 2.3, n=19$; complex, $2.4 \pm 2.1, n=13$; mean $\pm \mathrm{SD} ; p=0.02$, MannWhitney test). The difference in strength of nonpreferred eye input between simple and complex cells might reflect differences in monocularity (Fig. 2). Despite these differences, nonpreferred eye responses from both simple and complex cells indicate that binocular suppression cannot be predicted by a linear summation of right and left eye membrane potential responses. These membrane potential records suggest that synaptic inhibitory mechanisms, activated by binocular stimulation, may contribute to suppression induced by strabismus.

Synaptic inhibition has been the hypothesized cause of binocular suppression (Levi et al., 1979; Sengpiel and Blakemore, 1994; Sengpiel et al., 1994). Pharmacological experiments have provided strong evidence that inhibition underlies binocular suppression (Sengpiel et al., 2006). However, as the pharmacological agent in those experiments caused a large and widespread increase in spike rates, the experiments were unable to rule out that a loss of binocular suppression was due to a global increase in neuronal excitability (Sengpiel et al., 2006). We therefore sought a complementary test of the hypothesis by estimating excitatory and inhibitory inputs to single neurons without drastically affecting spike rates of surrounding neurons. In a few neurons, we estimated excitatory and inhibitory inputs from membrane potential responses recorded at different levels of injected current (Borg-Graham et al., 1998; Hirsch et al., 1998; Anderson et al., 2000a).

In neurons from normal animals, membrane potential depolarization evoked by the preferred binocular stimulus was greater than for stimulation of the preferred eye alone (Figs. $3 A, 7 A, B$, $8 A$, left). Likewise, peak synaptic excitation and inhibition evoked by the binocular stimulus was greater than that evoked by monocular stimulation (Fig. $8 A$, middle). A similar trend was evident across a population of neurons $(n=17)$ from normal animals $\left(G_{e}\right.$, binocular, $2.00 \pm 1.71 \mathrm{nS}$; preferred eye, $1.19 \pm 1.13$ $\mathrm{nS} ; p<0.05$, paired $t$ test; $G_{i}$, binocular, $1.55 \pm 1.51 \mathrm{nS}$; preferred eye, $1.12 \pm 1.18 \mathrm{nS} ; p<0.05$, paired $t$ test; $n=17$; mean $\pm \mathrm{SD}$ ). Membrane potential, synaptic excitation, and synaptic inhibition did not exhibit binocular suppression and the ratio of excitation to inhibition was generally unchanged across stimulus conditions, yielding no significant change across our sample population whether the mean, median, or geometric mean is compared (Fig. 8A, right). In contrast, in strabismic animals membrane potential depolarization evoked by the preferred binocular stimulus was less than that evoked by the preferred eye (Fig. $8 B, C$, left). Conductance estimates across our small population of neurons $(n=9)$ indicate an increase in inhibition for the preferred binocular stimulus, accompanied by little change in excitation 
A

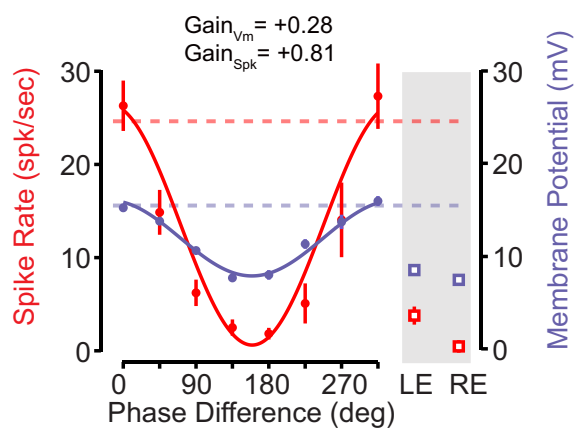

B

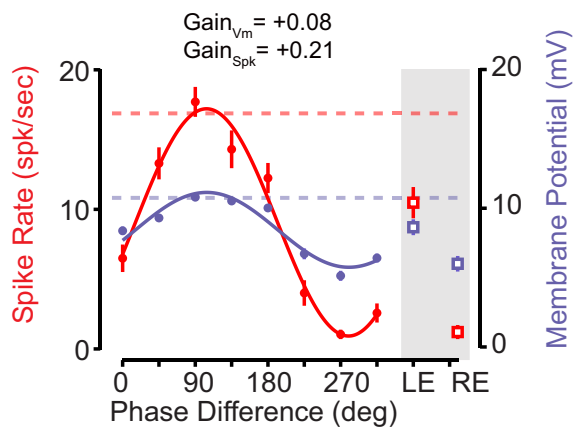

$\mathbf{E}$

Membrane Potential

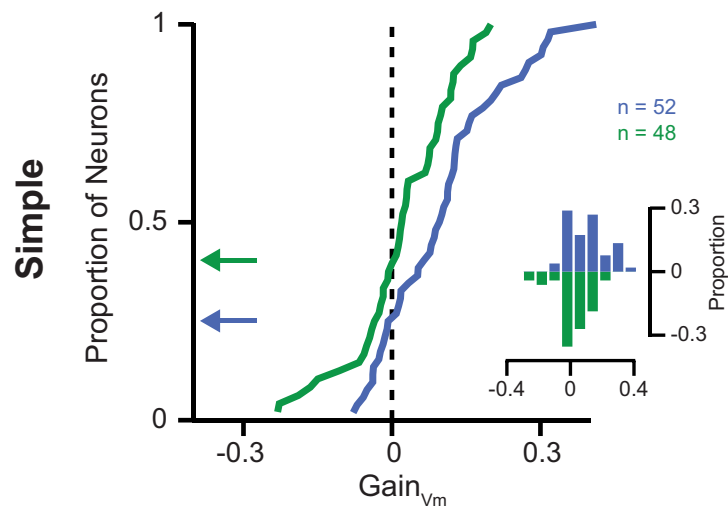

G

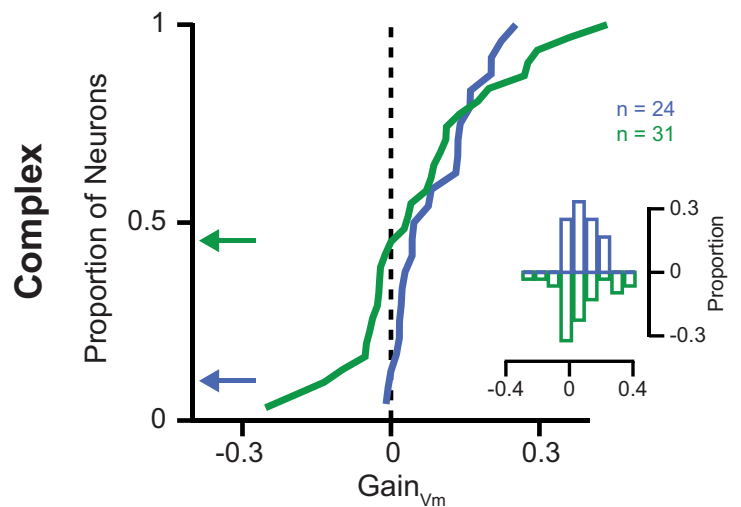

C Strabismic 边
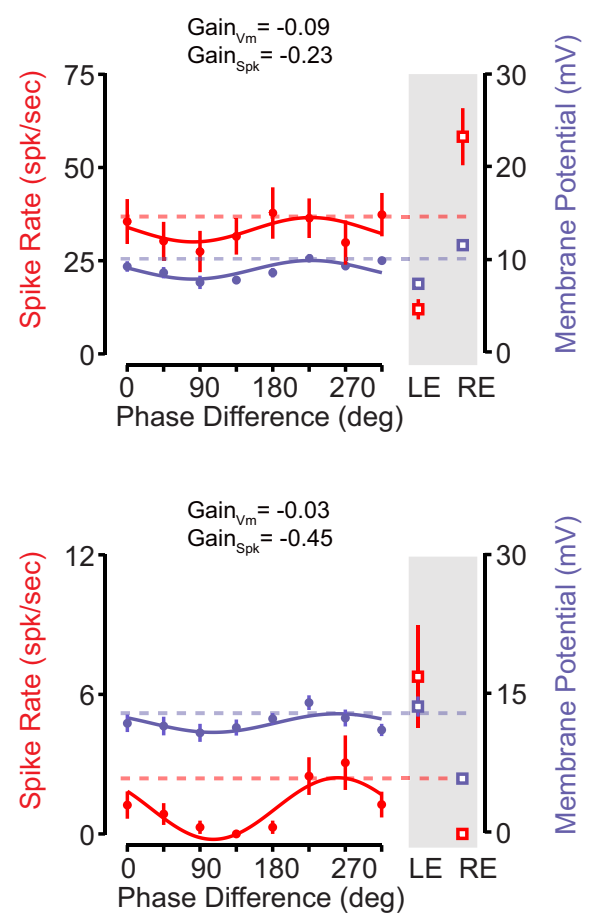

$\mathbf{F}$

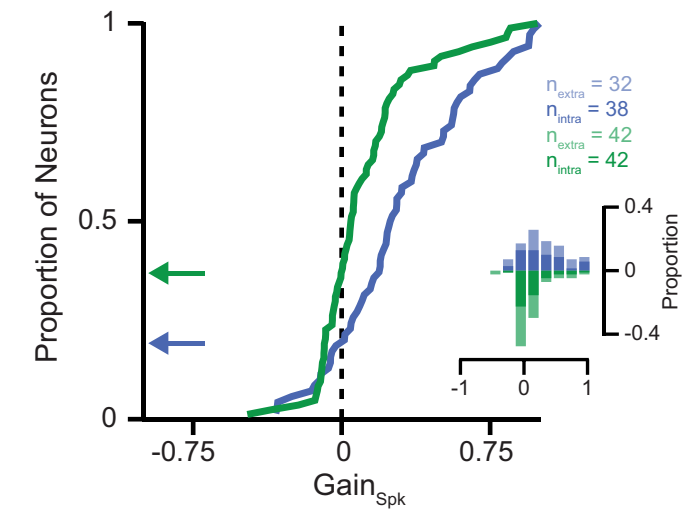

H

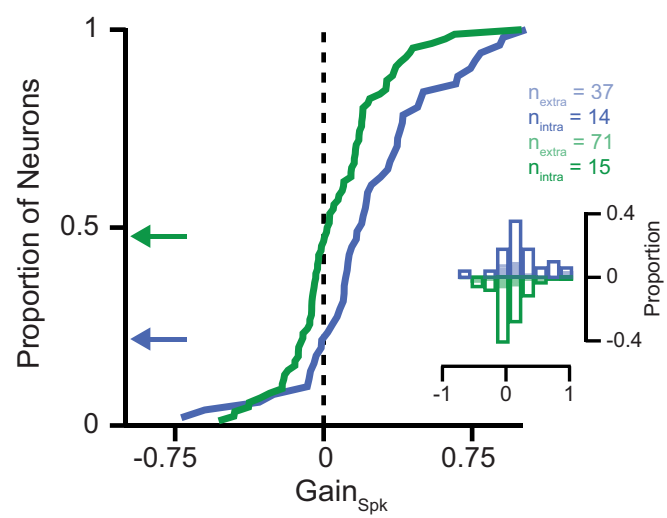

Figure 7. Binocular response suppression of membrane potential and spiking responses in neurons of primary visual cortex. $A$, Example neuron disparity tuning curve for subthreshold membrane potential (purple) and spiking (red) peak responses from a normal animal. Responses at preferred disparities $\left(0\right.$ and $\left.270^{\circ}\right)$ are much larger than the response from the preferred eye $(g r a y ~ s h a d i n g)$. Dashed lines indicate the amplitude of summed mean and modulation components of disparity tuning. Positive gain values (see Materials and Methods) reflect the large increase in binocular responses relative to stimulation of the preferred eye. $\boldsymbol{B}$, Same as in $\boldsymbol{A}$ for another unsuppressed neuron from a normal animal. $\boldsymbol{C}$, Same as in $\boldsymbol{A}$ for an example neuron from (Figure legend continues.) 

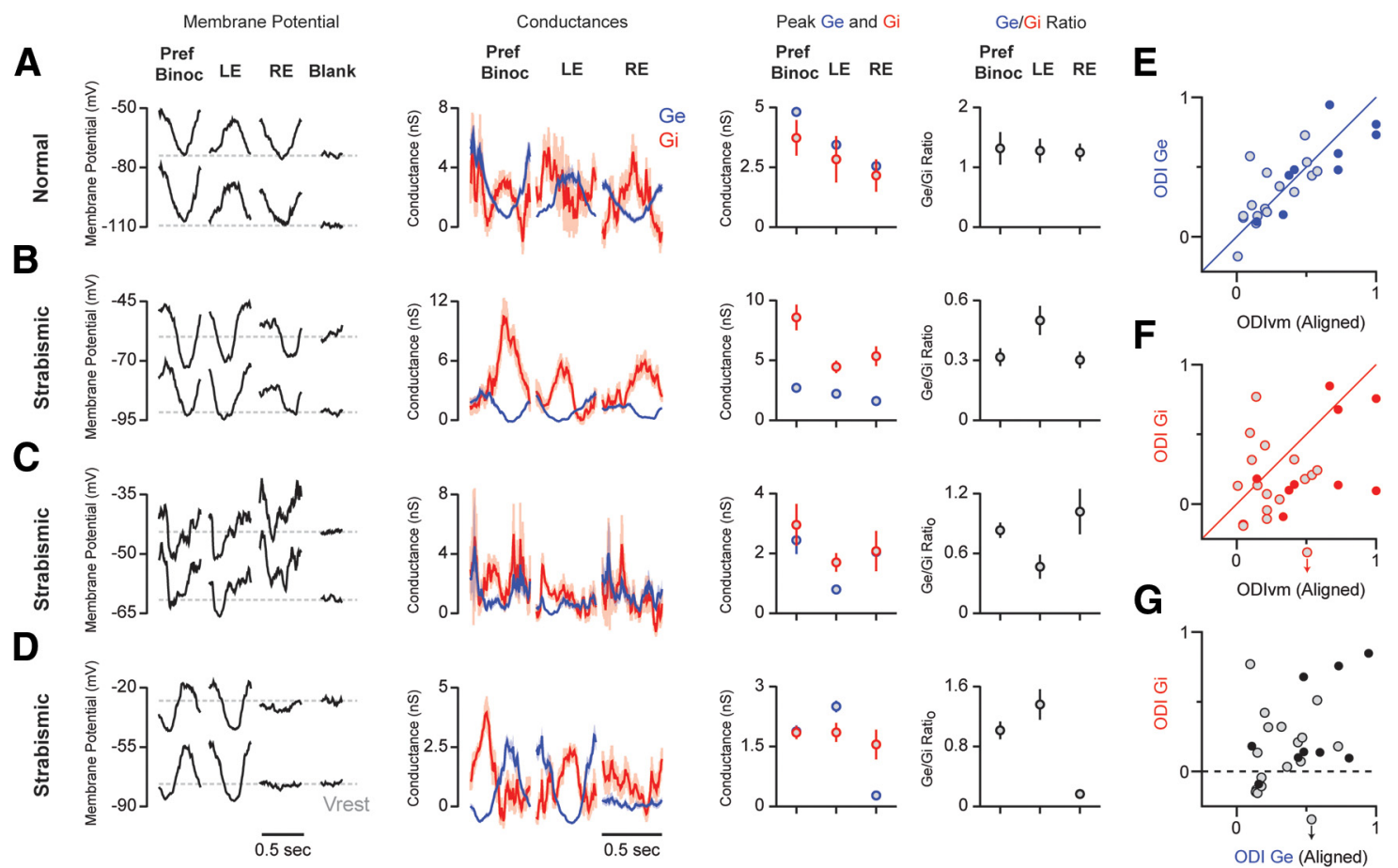

F
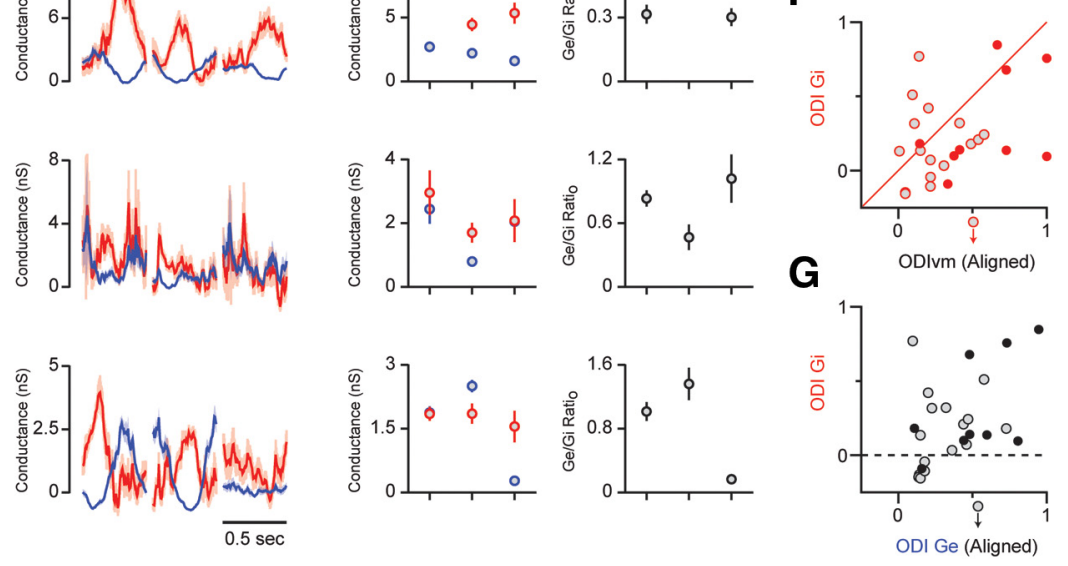

Figure 8. Subthreshold binocular suppression due to synaptic inhibition. $A$, Mean cycle-averaged membrane potential responses at two levels of current injection, excitatory (blue) and inhibitory (red) synaptic conductances, peak excitatory and inhibitory conductances, and ratio of excitation to inhibition for the preferred binocular disparity and monocular stimulation in an example neuron from the normal animal. $\boldsymbol{B}, \boldsymbol{C}$, Same as in $\boldsymbol{A}$ for binocular neurons from the strabismic animal. $\boldsymbol{D}$, Same as in $\boldsymbol{B}$ and $\boldsymbol{C}$ for a monocular neuron. The gray dashed line represents the resting membrane potential during mean-luminance (blank) periods for each level of current injection. Conductance traces, peak values, and excitation-to-inhibition ratios are plotted as mean and bootstrapped SE. $\boldsymbol{E}$, The ocular dominance index for the peak excitatory conductance is plotted relative to the ocular dominance index based on the peak membrane potential. Each symbol indicates a different neuron. Filled symbols indicate neurons recorded from strabismic animals, which are more monocular than neurons from normal animals, indicated by open symbols. The ocular dominance for $V_{\mathrm{m}}$ was aligned such that 0 indicates binocular and 1 indicates monocular dominance for the dominant eye (either contralateral or ipsilateral). This convention for ocular dominance is followed for the ordinate as well. Negative values on the ordinate therefore indicate preference for the opposite eye. $\boldsymbol{F}, \boldsymbol{G}$, The format follows that in $\boldsymbol{E}$, except that the ocular dominance index for inhibition is plotted relative to membrane potential $(\boldsymbol{F})$, or inhibition is plotted relative to excitation $(\boldsymbol{G})$. One neuron, indicated by the arrow, has a very negative ocular dominance score $(-0.78)$. LE, Left eye; RE, right eye.

$\left(G_{e}\right.$, binocular, $2.08 \pm 0.88 \mathrm{nS}$; preferred eye, $2.10 \pm 0.82 \mathrm{nS} ; p=$ 0.97 , paired $t$ test; $G_{i}$, binocular, $3.37 \pm 2.26 \mathrm{nS}$; preferred eye, $2.84 \pm 1.45 \mathrm{nS} ; p=0.31$, paired $t$ test; mean $\pm \mathrm{SD}$ ). For neurons in which membrane potential measurements demonstrated binocular suppression (Fig. $8 B-D$ ), the difference between excitation and inhibition in monocular and binocular conditions is more pronounced. For this subset of neurons (4 of 9), inhibition is dramatically increased by binocular stimulation relative to excitation $\left(G_{e} / G_{i}\right.$, binocular, $0.70 \pm 0.26$; preferred eye, $0.98 \pm 0.36$; $p<0.05$, paired $t$ test; mean \pm SD; Fig. $8 B-D$, right).

These results suggest that inhibition is playing a direct role in producing binocular suppression. Such inhibition could be generated by an antagonism between the representations of the two eyes, in which case the eye preference for inhibition should be opposite that for excitation. Alternatively, inhibition may simply be less monocular than excitation, such that binocular stimulation drives inhibition strongly. Our estimates of excitatory con-

\section{$\leftarrow$}

(Figure legend continued.) a strabismic animal. Slight suppression of membrane potential responses and large suppression of spiking responses are evident, represented by respective negative gain values. $\boldsymbol{D}$, Same as in $($ for another example neuron. $\boldsymbol{E}$, Cumulative distribution of gain values for subthreshold membrane potential in simple cells from normal (blue) and strabismic (green) animals. Gain values below 0 (dashed line) indicate binocular suppression. Arrows indicate the proportion of neurons suppressed by binocular stimulation. Gain value distributions are also shown (inset). $\boldsymbol{F}$, Same as in $\boldsymbol{E}$ for spiking responses. Spiking distributions include intracellular (dark shading) and extracellular (light shading) records. G, Same as in $\boldsymbol{E}$ for complex cells. $\boldsymbol{H}$, Same as in $\boldsymbol{F}$ for complex cells. LE, Left eye; RE, right eye. ductance indicate that the eye dominance evident in membrane potential is closely related to that found in the resulting membrane potential for neurons recorded in both normal and strabismic animals (Fig. $8 E$; not significant, $p=0.27$, paired $t$ test). Inhibition, in records from strabismic animals, is more binocular than either the resulting membrane potential (Fig. $8 F$; mean $\mathrm{MI}_{\mathrm{Gi}}, 0.33 ; \mathrm{MI}_{\mathrm{Vm}}, 0.60$; paired $t$ test, $p<0.05$ ) or excitation (Fig. $8 G$; mean $\mathrm{MI}_{\mathrm{Ge}}, 0.53$ ), although there is considerable variability on a cell-by-cell basis. While inhibition is more binocular than excitation, it nonetheless shares overall eye preference with excitation. Therefore, the decline in the excitatory-to-inhibitory ratio observed in suppressed neurons (Fig. $8 B-D$ ) results from inhibition being more broadly tuned for eye preference and being driven better by binocular stimulation instead of an antagonism between the two eye representations. Our conductance measurements therefore suggest that increased inhibition evoked by the preferred binocular stimulus could account for binocular response suppression and facilitate the loss of binocular convergence observed in strabismic animals. These indications from our limited sample must be tested by more extensive measurements.

\section{Discussion}

Primary visual cortex is the first site of binocular integration leading to seamless visual perception and stereoscopic depth perception (Ohzawa et al., 1990; DeAngelis et al., 1991; Cumming and Parker, 1997; Cumming and DeAngelis, 2001). The effects of strabismus in V1 were studied previously by extracellular recording of spiking responses, leaving the underlying subthreshold 
A

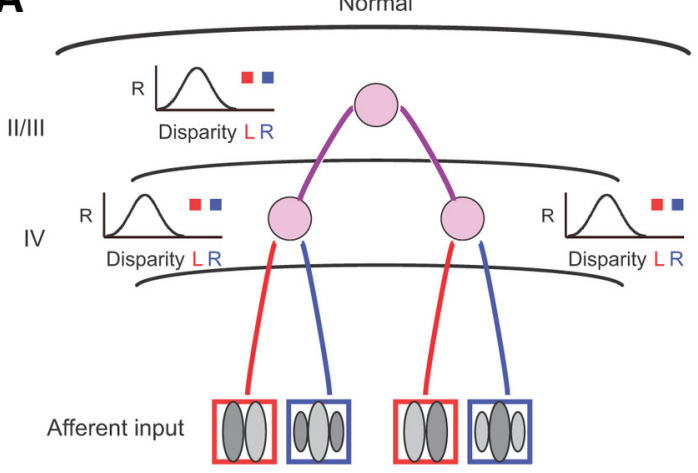

B

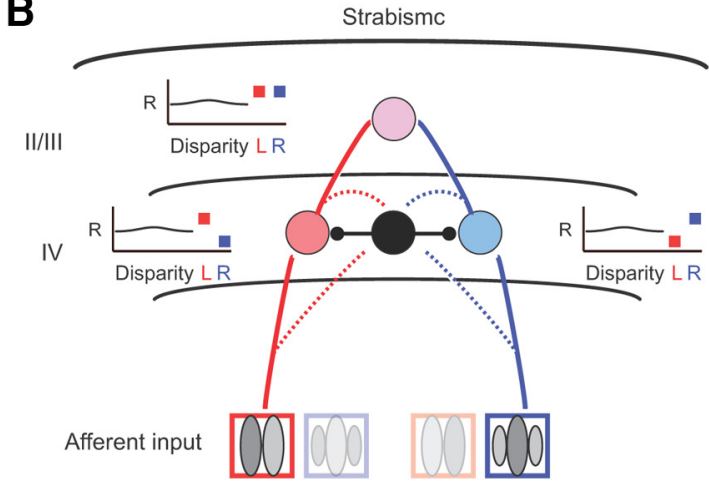

Figure 9. Loss of thalamic input in circuit model of strabismus. $\boldsymbol{A}$, Left (L) and right (R) eye inputs converge on layer 4 simple cells, generating disparity selectivity. Simple cell inputs converge onto complex cells in layer $2 / 3$, which are also disparity selective. $\boldsymbol{B}$, In strabismic animals, simple cells receive monocular input. A loss of binocularity causes a loss of disparity selectivity, which also occurs in complex cells through feedforward inputs. Complex cells receive inputs from simple cells and thus can be binocular. Suppression of binocular responses is mediated by inhibitory interneurons receiving input from thalamocortical inputs and simple cells. In this simple model, the strabismus-induced changes are qualitatively similar for all neurons regardless of the initial difference in synaptic strength, spatial selectivity, and spatial phase between the inputs from each eye to the neuron.

synaptic inputs unknown (Hubel and Wiesel, 1965; Blakemore, 1976; Crewther et al., 1985; Chino et al., 1994; Roelfsema et al., 1994; Sengpiel and Blakemore, 1994; Sengpiel et al., 1994, 2006; Fries et al., 1997; Smith et al., 1997; Schmidt et al., 2004; Ranson et al., 2012). Using intracellular recordings, we found that strabismus increased monocularity in simple cells, but not in complex cells. Simple and complex cells both exhibited decreased disparity selectivity, and an increased occurrence of binocular suppression. Finally, our estimates of excitatory and inhibitory synaptic input onto single neurons indicate that binocular suppression was the result of an imbalance in the ratio of excitation and inhibition. Inhibition shared eye preference with excitation, but was more binocular than excitation. Inhibition therefore increased to a greater degree than excitation in response to binocular stimulation, which leads to an overall response suppression.

We outline a diagrammatic circuit model for the changes induced by strabismus based on the disparity energy model (Anzai et al., 1999a,b; Fig. 9). In normal animals, simple cells receive thalamic excitatory input from left and right eyes (Fig. 9, left). Net excitation from each eye is selective for spatial phase, and thus temporally modulated by sinusoidal stimuli. Disparity selectivity with binocular stimulation results because the two eyes provide correlated excitation only at a particular relative spatial phase. Complex cells receive excitatory input from multiple simple cells with a wide range of spatial phase selectivity and a narrow range of disparity selectivity, and have responses that are not temporally modulated by sinusoidal stimuli but are disparity tuned. Because simple cell inputs to complex cells do not have identical disparity selectivity, net synaptic input to a complex cell is less disparity selective than spiking responses from simple cells. Neurons in normal animals also receive synaptic inhibition that contains components with various degrees of selectivity for spatial phase (Azouz et al., 1997; Borg-Graham et al., 1998; Hirsch et al., 1998, 2003; Monier et al., 2003; Cardin et al., 2008; Nowak et al., 2008).

In this model, strabismus causes each simple cell to lose excitatory input from one of the eyes as a result of Hebbian or Hebbian-like spike-timing-dependent plasticity (Miller et al., 1989; Song et al., 2000; Gütig et al., 2003; Fig. 9, right). Because of the loss of excitatory input from one eye, simple cells become more monocular and less disparity tuned. Complex cells remain binocular because they receive inputs from left and right eyepreferring simple cells, but are less disparity selective because those simple cells that provide feedforward drive are less disparity tuned. Because the input to inhibitory neurons is unchanged, inhibition onto simple cells remains. The increased ratio of inhibition to excitation results in binocular suppression of simple cells. Complex cells, which receive input from simple cells, inherit simple cell binocular suppression. Suppression could be derived from binocular layer 4 inhibitory cells or from the convergence of multiple monocular inhibitory cells that span ocular preference. We therefore argue that plasticity only at thalamocortical synapses is sufficient to account for our observations.

Notably, each neuron's disparity selectivity depends on the spatial selectivity of its inputs, and a variety of weights are needed to generate the full range of disparity tuning observed (Anzai et al., 1999a,b; Schmidt and Löwel, 2006, 2008; Jaffer et al., 2012). In our simple model, the general nature of strabismus is the same regardless of the differences in synaptic strength, spatial selectivity, and spatial phase between inputs from each eye to each neuron. It is possible that the quantitative extent of induced changes by strabismus does depend on such initial differences, but we do not have the data to determine these dependencies. Our simple model is thus only qualitative with respect to such possible dependencies.

The plausibility of strabismus causing changes mainly at thalamocortical synapses is consistent with evidence that the thalamocortical synapse is also the site of plasticity following monocular deprivation (Khibnik et al., 2010; Wang et al., 2013), but differs from conclusions from other groups. For example, monocular deprivation is known to induce changes in the spiking responses first of supragranular neurons and then subsequently of thalamorecipient neurons (Diamond et al., 1994; Trachtenberg et al., 2000), indicating that plasticity emerges through cortical interactions first. One potential resolution to this apparent discrepancy is that supragranular neurons receive input from several thalamorecipient neurons and perform an effective averaging that renders weak changes in thalamorecipient neurons more visible. Furthermore, thresholding synaptic inputs in the supragranular neurons would further enhance any slight change in their subthreshold ocular dominance (Priebe and Ferster, 2008; Priebe, 2008). Another argument against the minimal model we diagrammed is the observation of changes in the inhibitory network following monocular deprivation, as shown by changes in visual responses of inhibitory neurons (YazakiSugiyama et al., 2009) and the potentiated inhibitory synapses 
onto excitatory neurons after monocular deprivation (Maffei et al., 2004, 2006). The net inhibition onto excitatory neurons might be unchanged if thalamic input onto inhibitory neurons is weakened, but is compensated for by strengthened inhibitory inputs onto excitatory neurons (House et al., 2011). Finally, the rules of plasticity responsible for such changes may be different than the simple Hebbian rule we assumed for thalamocortical synapses onto excitatory simple cells (Bell et al., 1997; McBain et al., 1999; Holmgren and Zilberter, 2001; Woodin et al., 2003; Tzounopoulos et al., 2004; Haas et al., 2006; Lu et al., 2007; Caporale and Dan, 2008; Kullmann et al., 2012). Indeed, monocular deprivation experiments indicate that even Hebbian plasticity may be inadequate over long time scales, and changes are supplemented with homeostatic mechanisms (Mrsic-Flogel et al., 2007; Maffei and Turrigiano, 2008; Ranson et al., 2012).

Not only is ocular misalignment a primary example of experience-dependent learning, but it is a common visual disorder found in humans. We have demonstrated profound celltype-specific changes in synaptic drive following exotropic strabismus. Along with the disruption of right and left eye integration, we also find that inhibitory interactions contribute to the loss of cortical circuitry underlying binocularity. In particular we have found that the inhibitory network associated with strabismus is not solely based on an antagonism between the eyes, but instead acts to suppress binocular integration. A common treatment to preserve cortical responses to both eyes has been to patch the stronger eye, but this may not be helpful in the recovery of stereo vision. Instead, therapies that actively engage both eyes during visual tasks result in improvements of stereo vision (Li et al., 2011, 2013). These therapies may in fact be altering the inhibitory network that has developed to prevent diplopia and thus aiding in the recovery of proper depth perception.

\section{References}

Anderson JS, Carandini M, Ferster D (2000a) Orientation tuning of input conductance, excitation, and inhibition in cat primary visual cortex. J Neurophysiol 84:909-926. Medline

Anderson JS, Lampl I, Gillespie DC, Ferster D (2000b) The contribution of noise to contrast invariance of orientation tuning in cat visual cortex. Science 290:1968-1972. CrossRef Medline

Anzai A, Ohzawa I, Freeman RD (1999a) Neural mechanisms for processing binocular information II. Complex cells. J Neurophysiol 82:909-924. Medline

Anzai A, Ohzawa I, Freeman RD (1999b) Neural mechanisms for processing binocular information I. Simple cells. J Neurophysiol 82:891-908. Medline

Azouz R, Gray CM, Nowak LG, McCormick DA (1997) Physiological properties of inhibitory interneurons in cat striate cortex. Cereb Cortex 7:534545. CrossRef Medline

Bell CC, Han VZ, Sugawara Y, Grant K (1997) Synaptic plasticity in a cerebellum-like structure depends on temporal order. Nature 387:278281. CrossRef Medline

Blakemore C (1976) The conditions required for the maintenance of binocularity in the kitten's visual cortex. J Neurophysiol 261:423-444.

Borg-Graham LJ, Monier C, Frégnac Y (1998) Visual input evokes transient and strong shunting inhibition in visual cortical neurons. Nature 393: 369-373. CrossRef Medline

Brainard DH (1997) The psychophysics toolbox. Spat Vis 10:433-436. CrossRef Medline

Caporale N, Dan Y (2008) Spike timing-dependent plasticity: a Hebbian learning rule. Annu Rev Neurosci 31:25-46. CrossRef Medline

Cardin JA, Palmer LA, Contreras D (2008) Cellular mechanisms underlying stimulus-dependent gain modulation in primary visual cortex neurons in vivo. Neuron 59:150-160. CrossRef Medline

Celebrini S, Thorpe S, Trotter Y, Imbert M (1993) Dynamics of orientation coding in area V1 of the awake primate. Vis Neurosci 10:811-825. CrossRef Medline
Chen Y, Geisler WS, Seidemann E (2008) Optimal temporal decoding of neural population responses in a reaction-time visual detection task. J Neurophysiol 99:1366-1379. CrossRef Medline

Chino YM, Shansky MS, Jankowski WL, Banser FA (1983) Effects of rearing kittens with convergent strabismus on development of receptive field properties in striate cortex neurons. J Neurophysiol 50:265-286. Medline

Chino YM, Ridder WH 3rd, Czora EP (1988) Effects of convergent strabismus on spatio-temporal response properties of neurons in cat area 18. Exp Brain Res 72:264-278. Medline

Chino YM, Smith EL 3rd, Yoshida K, Cheng H, Hamamoto J (1994) Binocular interactions in striate cortical neurons of cats reared with discordant visual inputs. J Neurosci 14:5050-5067. Medline

Chung S, Ferster D (1998) Strength and orientation tuning of the thalamic input to simple cells revealed by electrically evoked cortical suppression. Neuron 20:1177-1189. CrossRef Medline

Crewther SG, Crewther DP, Cleland BG (1985) Convergent strabismic amblyopia in cats. Exp Brain Res 60:1-9. Medline

Cumming BG, DeAngelis GC (2001) The physiology of stereopsis. Annu Rev Neurosci 24:203-238. CrossRef Medline

Cumming BG, Parker AJ (1997) Responses of primary visual cortical neurons to binocular disparity without depth perception. Nature 389:280283. CrossRef Medline

DeAngelis GC, Ohzawa I, Freeman RD (1991) Depth is encoded in the visual cortex by a specialized receptive field structure. Nature 352:156-159. CrossRef Medline

Diamond ME, Huang W, Ebner FF (1994) Laminar comparison of somatosensory cortical plasticity. Science 265:1885-1888. CrossRef Medline

Economides JR, Adams DL, Horton JC (2012) Perception via the deviated eye in strabismus. J Neurosci 32:10286-10295. CrossRef Medline

Engelmann R, Crook JM, Löwel S (2002) Optical imaging of orientation and ocular dominance maps in area 17 of cats with convergent strabismus. Vis Neurosci 19:39-49. Medline

Ferster D, Jagadeesh B (1992) EPSP-IPSP interactions in cat visual cortex studied with in vivo whole-cell patch recording. J Neurosci 12:1262-1274. Medline

Ferster D, Chung S, Wheat H (1996) Orientation selectivity of thalamic input to simple cells of cat visual cortex. Nature 380:249-252. CrossRef Medline

Frazor RA, Albrecht DG, Geisler WS, Crane AM (2004) Visual cortex neurons of monkeys and cats: temporal dynamics of the spatial frequency response function. J Neurophysiol 91:2607-2627. CrossRef Medline

Freeman RD, Tsumoto T (1983) An electrophysiological comparison of convergent and divergent strabismus in the cat: electrical and visual activation of single cortical cells. J Neurophysiol 49:238-253. Medline

Fries P, Roelfsema PR, Engel AK, König P, Singer W (1997) Synchronization of oscillatory responses in visual cortex correlates with perception in interocular rivalry. Proc Natl Acad Sci U S A 94:12699-12704. CrossRef Medline

Gawne TJ, Kjaer TW, Richmond BJ (1996) Latency: another potential code for feature binding in striate cortex. J Neurophysiol 76:1356-1360. Medline

Gütig R, Aharonov R, Rotter S, Sompolinsky H (2003) Learning input correlations through nonlinear temporally asymmetric Hebbian plasticity. J Neurosci 23:3697-3714. Medline

Haas JS, Nowotny T, Abarbanel HD (2006) Spike-timing-dependent plasticity of inhibitory synapses in the entorhinal cortex. J Neurophysiol 96: 3305-3313. CrossRef Medline

Hansel D, van Vreeswijk C (2002) How noise contributes to contrast invariance of orientation tuning in cat visual cortex. J Neurosci 22:5118-5128. Medline

Hensch TK (2004) Critical period regulation. Annu Rev Neurosci 27:549579. CrossRef Medline

Hirsch JA, Alonso JM, Reid RC, Martinez LM (1998) Synaptic integration in striate cortical simple cells. J Neurosci 18:9517-9528. Medline

Hirsch JA, Martinez LM, Pillai C, Alonso JM, Wang Q, Sommer FT (2003) Functionally distinct inhibitory neurons at the first stage of visual cortical processing. Nat Neurosci 6:1300-1308. CrossRef Medline

Holmgren CD, Zilberter Y (2001) Coincident spiking activity induces longterm changes in inhibition of neocortical pyramidal cells. J Neurosci 21: 8270-8277. Medline

House DR, Elstrott J, Koh E, Chung J, Feldman DE (2011) Parallel regula- 
tion of feedforward inhibition and excitation during whisker map plasticity. Neuron 72:819-831. CrossRef Medline

Hubel DH, Wiesel TN (1965) Binocular interaction in striate cortex of kittens reared with artificial squint. J Neurophysiol 28:1041-1059. Medline

Huberman AD, Feller MB, Chapman B (2008) Mechanisms underlying development of visual maps and receptive fields. Annu Rev Neurosci 31: 479-509. CrossRef Medline

Jaffer S, Vorobyov V, Sengpiel F (2012) Effects of different forms of monocular deprivation on primary visual cortex maps. Vis Neurosci 29:247253. CrossRef Medline

Katz LC, Crowley JC (2002) Development of cortical circuits: lessons from ocular dominance columns. Nat Rev Neurosci 3:34-42. CrossRef Medline

Khibnik LA, Cho KK, Bear MF (2010) Relative contribution of feedforward excitatory connections to expression of ocular dominance plasticity in layer 4 of visual cortex. Neuron 66:493-500. CrossRef Medline

Kalil RE, Spear PD, Langsetmo A (1984) Response properties of striate cortex neurons in cats raised with divergent of convergent strabismus. J Neurophysiol 52:514-537. Medline

Kullmann DM, Moreau AW, Bakiri Y, Nicholson E (2012) Plasticity of inhibition. Neuron 75:951-962. CrossRef Medline

LeVay S, Voigt T (1988) Ocular dominance and disparity coding in cat visual cortex. Vis Neurosci 1:395-414. CrossRef Medline

Levi DM, Harwerth RS, Smith EL 3rd (1979) Humans deprived of normal binocular vision have binocular interactions tuned to size and orientation. Science 206:852-854. CrossRef Medline

Li J, Thompson B, Deng D, Chan LYL, Yu M, Hess RF (2013) Dichoptic training enables the adult amblyopic brain to learn. Curr Bio 23:R308R309. CrossRef

Li RW, Ngo C, Nguyen J, Levi DM (2011) Video-game play induces plasticity in the visual system of adults with amblyopia. PLoS Biol 9:e1001135. CrossRef Medline

Löwel S (1994) Ocular dominance column development: strabismus changes the spacing of adjacent columns in cat visual cortex. J Neurosci 14:7451-7468. Medline

Löwel S, Schmidt KE, Kim DS, Wolf F, Hoffsümmer F, Singer W, Bonhoeffer $\mathrm{T}$ (1998) The layout of orientation and ocular dominance domains in area 17 of strabismic cats. Europ J Neurosci 10:2629-2643. CrossRef

Lu JT, Li CY, Zhao JP, Poo MM, Zhang XH (2007) Spike-timing-dependent plasticity of neocortical excitatory synapses on inhibitory interneurons depends on target cell type. J Neurosci 27:9711-9720. CrossRef Medline

Maffei A, Turrigiano GG (2008) Multiple modes of network homeostasis in visual cortical layer 2/3. J Neurosci 28:4377-4384. CrossRef Medline

Maffei A, Nelson SB, Turrigiano GG (2004) Selective reconfiguration of layer 4 visual cortical circuitry by visual deprivation. Nat Neurosci 7:1353-1359. CrossRef Medline

Maffei A, Nataraj K, Nelson SB, Turrigiano GG (2006) Potentiation of cortical inhibition by visual deprivation. Nature 443:81-84. CrossRef Medline

Margrie TW, Brecht M, Sakmann B (2002) In vivo, low-resistance, wholecell recordings from neurons in the anaesthetized and awake mammalian brain. Europ J Physiol 444:491-498. CrossRef

Martinez LM, Wang Q, Reid RC, Pillai C, Alonso JM, Sommer FT, Hirsch JA (2005) Receptive field structure varies with layer in the primary visual cortex. Nat Neurosci 8:372-379. CrossRef Medline

McBain CJ, Freund TF, Mody I (1999) Glutamatergic synapses onto hippocampal interneurons: precision timing without lasting plasticity. Trends Neurosci 22:228-235. CrossRef Medline

Miller KD, Troyer TW (2002) Neural noise can explain expansive, powerlaw nonlinearities in neural response functions. J Neurophysiol 87:653659. Medline

Miller KD, Keller JB, Stryker MP (1989) Ocular dominance column development: analysis and simulation. Science 245:605-615. CrossRef Medline

Monier C, Chavane F, Baudot P, Graham LJ, Frégnac Y (2003) Orientation and direction selectivity of synaptic inputs in visual cortical neurons: a diversity of combinations produces spike tuning. Neuron 37:663-680. CrossRef Medline

Mrsic-Flogel TD, Hofer SB, Ohki K, Reid RC, Bonhoeffer T, Hübener M (2007) Homeostatic regulation of eye-specific responses in visual cortex during ocular dominance plasticity. Neuron 54:961-972. CrossRef Medline
Müller JR, Metha AB, Krauskopf J, Lennie P (2001) Information conveyed by onset transients in responses of striate cortical neurons. J Neurosci 21:6978-6990. Medline

Nowak LG, Sanchez-Vives MV, McCormick DA (2008) Lack of orientation and direction selectivity in a subgroup of fast-spiking inhibitory interneurons: cellular and synaptic mechanisms and comparison with other electrophysiological cell types. Cereb Cortex 18:1058-1078. CrossRef Medline

Ohzawa I, Freeman RD (1986a) The binocular organization of simple cells in the cat's visual cortex. J Neurophysiol 56:221-242. Medline

Ohzawa I, Freeman RD (1986b) The binocular organization of complex cells in the cat's visual cortex. J Neurophysiol 56:243-259. Medline

Ohzawa I, DeAngelis GC, Freeman RD (1990) Stereoscopic depth discrimination in the visual cortex: neurons ideally suited as disparity detectors. Science 249:1037-1041. CrossRef Medline

Palmer C, Cheng SY, Seidemann E (2007) Linking neuronal and behavioral performance in a reaction-time visual detection task. J Neurosci 27:81228137. CrossRef Medline

Pei X, Volgushev M, Vidyasagar TR, Creutzfeldt OD (1991) Whole cell recording and conductance measurements in cat visual cortex in-vivo. Neuroreport 2:485-488. CrossRef Medline

Pelli DG (1997) The VideoToolbox software for visual psychophysics: transforming numbers into movies. Spatial Vis 10:437-442. CrossRef

Priebe NJ (2008) The relationship between subthreshold and suprathreshold ocular dominance in cat primary visual cortex. J Neurosci 28:85538559. CrossRef Medline

Priebe NJ, Ferster D (2006) Mechanisms underlying cross-orientation suppression in cat visual cortex. Nat Neurosci 9:552-561. CrossRef Medline

Priebe NJ, Ferster D (2008) Inhibition, spike threshold, and stimulus selectivity in primary visual cortex. Neuron 57:482-497. CrossRef Medline

Priebe NJ, Mechler F, Carandini M, Ferster D (2004) The contribution of spike threshold to the dichotomy of cortical simple and complex cells. Nat Neurosci 7:1113-1122. CrossRef Medline

Ranson A, Cheetham CE, Fox K, Sengpiel F (2012) Homeostatic plasticity mechanisms are required for juvenile, but not adult, ocular dominance plasticity. Proc Natl Acad Sci U S A 109:1311-1316. CrossRef Medline

Read JC, Cumming BG (2004) Ocular dominance predicts neither strength nor class of disparity selectivity with random-dot stimuli in primate V1. J Neurophysiol 91:1271-1281. Medline

Reich DS, Mechler F, Victor JD (2001) Temporal coding of contrast in primary visual cortex: when, what, and why. J Neurophysiol 85:1039-1050. Medline

Ringach DL, Shapley RM, Hawken MJ (2002) Orientation selectivity in macaque V1: diversity and laminar dependence. J Neurosci 22:5639-5651. Medline

Roelfsema PR, Konig P, Engel AK, Sireteanu R, Singer W (1994) Reduced synchronization in the visual cortex of cats with strabismic amblyopia. Europ J Neurosci 6:1645-1655. CrossRef

Schmidt KE, Singer W, Galuske RA (2004) Processing deficits in primary visual cortex of amblyopic cats. J Neurophysiol 91:1661-1671. CrossRef Medline

Schmidt KF, Löwel S (2006) Optical imaging in cat area 18: Strabismus does not enhance the segregation of ocular dominance domains. Neuroimage 29:439-445. CrossRef Medline

Schmidt KF, Löwel S (2008) Strabismus modifies intrinsic and inter-areal connections in cat area 18. Neuroscience 152:128-137. CrossRef Medline

Scholl B, Burge J, Priebe NJ (2013) Binocular integration and disparity selectivity in mouse primary visual cortex. J Neurophysiol 109:3013-3024. CrossRef Medline

Sengpiel F, Blakemore C (1994) Interocular control of neuronal responsiveness in cat visual cortex. Nature 368:847-850. CrossRef Medline

Sengpiel F, Blakemore C, Kind PC, Harrad R (1994) Interocular suppression in the visual cortex of strabismic cats. J Neurosci 14:6855-6871. Medline

Sengpiel F, Jirmann KU, Vorobyov V, Eysel UT (2006) Strabismic suppression is mediated by inhibitory interactions in the primary visual cortex. Cereb Cortex 16:1750-1758. Medline

Shatz CJ, Lindström S, Wiesel TN (1977) The distribution of afferents representing the right and left eyes in the cat's visual cortex. Brain Res 131: 103-116. CrossRef Medline

Shriki O, Kohn A, Shamir M (2012) Fast coding of orientation in primary visual cortex. PLoS Comput Biol 8:e1002536. CrossRef Medline 
Skottun BC, De Valois RL, Grosof DH, Movshon JA, Albrecht DG, Bonds AB (1991) Classifying simple and complex cells on the basis of response modulation. Vis Res 31:1079-1086. Medline

Smith EL 3rd, Chino YM, Ni J, Cheng H, Crawford ML, Harwerth RS (1997) Residual binocular interactions in the striate cortex of monkeys reared with abnormal binocular vision. J Neurophysiol 78:13531362. Medline

Sokal RR, Rohlf FJ (1995) Biometry: the principles and practice of statistics in biological research, 3rd edition. New York: W.H. Freeman.

Song S, Miller KD, Abbott LF (2000) Competitive Hebbian learning through spike-timing-dependent synaptic plasticity. Nat Neurosci 3:919926. CrossRef Medline

Swindale NV (1998) Orientation tuning curves: empirical description and estimation of parameters. Bio Cybernetics 78:45-56. CrossRef

Trachtenberg JT, Trepel C, Stryker MP (2000) Rapid extragranular plasticity in the absence of thalamocortical plasticity in the developing primary visual cortex. Science 287:2029-2032. CrossRef Medline

Tzounopoulos T, Kim Y, Oertel D, Trussell LO (2004) Cell-specific, spike timing-dependent plasticities in the dorsal cochlear nucleus. Nat Neurosci 7:719-725. CrossRef Medline

Von Noorden GK, Campos EC (2002) Binocular vision and ocular motility: theory and management of strabismus, Ed 6. St. Louis: Mosby.

Wang L, Kloc M, Gu Y, Ge S, Maffei A (2013) Layer-specific experiencedependent rewiring of thalamocortical circuits. J Neurosci 33:4181-4191. CrossRef Medline

Woodin MA, Ganguly K, Poo MM (2003) Coincident pre- and postsynaptic activity modifies GABAergic synapses by postsynaptic changes in $\mathrm{Cl}-$ transporter activity. Neuron 39:807-820. CrossRef Medline

Yazaki-Sugiyama Y, Kang S, Câteau H, Fukai T, Hensch TK (2009) Bidirectional plasticity in fast-spiking GABA circuits by visual experience. Nature 462:218-221. CrossRef Medline

Yinon U, Auerbach E (1975) The ocular dominance of cortical neurons in cats developed with divergence and convergent squint. Vis Res 15:12511256. Medline

Yu J, Ferster D (2010) Membrane potential synchrony in primary visual cortex during sensory stimulation. Neuron 68:1187-1201. CrossRef Medline 